\title{
LITOLOGIA, GENEZA I WIEK OSADÓW W KALNIKOWIE I CHOTYŃCU NA PŁASKOWYŻU TARNOGRODZKIM (KOTLINA SANDOMIERSKA)
}

\author{
Lithology, origin and age of sediments in the Kalników and Chotyniec in the Tarnogród \\ Plateau (Sandomierz Basin)
}

\author{
PIOTR GĘBICA*, SŁAWOMIR SUPERSON**, KATARZYNA TRYBAŁA-ZAWIŚLAK ${ }^{* * *}$, \\ BARBARA WORONKO****
}

\begin{abstract}
Zarys treści. Artykuł omawia wyniki analiz uziarnienia, obróbki ziarn kwarcu i datowań metodą OSL zróżnicowanych pod względem pochodzenia i wieku osadów czwartorzędowych (osady eoliczne, rzeczne, fluwioglacjalne) występujących na stanowiskach archeologicznych w południowej części Płaskowyżu Tarnogrodzkiego. Osady wydmowe w Kalnikowie-Zagrebli miąższości 1,2 m charakteryzują się dominacją ziarn drobnoziarnistych o średniej średnicy Mz=2,9 phi. Tak drobnoziarniste osady są rzadko spotykane w wydmach z późnego glacjału w Kotlinie Sandomierskiej. Depozycja piasków wydmowych na podstawie datowań OSL miała miejsce w młodszym dryasie. Osady budujące podłoże wydmy, to piaski drobnoziarniste z poziomami bruków żwirowych pochodzenia fluwioglacjalnego, które jak wykazała obróbka ziarn kwarcu, znajdują się na wtórnym złożu. Terasę nadzalewową Wiszni o wysokości 6-8 m n.p.rz. budują warstwowane horyzontalnie drobnoziarniste utwory piaszczyste, które na powierzchni terasy tworzą wał przykorytowy. Cechy strukturalne osadów oraz rozkład parametrów uziarnienia wskazują, że akumulowane były w strefie przykorytowej równi zalewowej. Analiza osadów pylastopiaszczystych pokrywających wierzchowinę płaskowyżu w otoczeniu wału grodziska z okresu celtyckiego w Chotyńcu wykazała, że nie są to utwory pochodzenia wietrzeniowego, ale prawdopodobnie osady genezy eolicznej.
\end{abstract}

Słowa kluczowe: uziarnienie osadów, obróbka ziarn kwarcu, datowanie OSL, stanowiska archeologiczne, Płaskowyż Tarnogrodzki

\begin{abstract}
The article presents the results of grain size, quartz grain roundness analysis and OSL datings, differing in origin and age of the Quaternary deposits (aeolian, fluvial, fluvioglacial) occurring in the archaeological sites in the southern part of the Tarnogród Plateau. The dune sediments in the Kalników-Zagrebla site of a thickness of $1.2 \mathrm{~m}$ are characterized by the domination of fine grains with the mean diameter $\mathrm{Mz}=2.9$ phi. Such fine sediments are unusual in the Late Glacial dunes in the Sandomierz Basin. The deposition of the dune was dated by the OSL to the Younger Dryas. The dunes are underlain by fine sands with thin gravel horizons of fluvioglacial origin, which represent the redeposited sediments according to quartz grain roundness analysis. The terrace of the Wisznia River 6-8 $\mathrm{m}$ above the river channel is built of horizontally bedded fine sands, which form the natural levees on the terrace surface. Structural features and the distribution of grain size parametres indicate, that sands were accumulated in the proximal part of the floodplain. An analysis of the silty-sandy sediments covering the plateau around the hill-fort rampart from the Celtic Period in Chotyniec site, excluded their weathering origin and proved their aeolian genesis.
\end{abstract}

Key words: grain size, quartz grain roundness, OSL dating, archaeological sites, Tarnogród Plateau

\section{Wprowadzenie}

Utwory czwartorzędowe Płaskowyżu Tarnogrodzkim (Kotlina Sandomierska), poza pracami związanymi z kartowaniem $\mathrm{w}$ ramach Atlasu Geologicznego Galicji (Łomnicki 1900), nie do- czekały się kompleksowych opracowań. Dostępne prace traktują jedynie o wybranych zagadnieniach geologii czwartorzędu tego rejonu. Butrym (1968) zajął się utworami pyłowymi Płaskowyżu Tarnogrodzkiego. Na podstawie znacznego udziału frakcji piasku w składzie granulometrycznym utworów powierzchniowych przyjął, że powstały

\footnotetext{
* Wyższa Szkoła Informatyki i Zarządzania w Rzeszowie, ul. Sucharskiego 2, 35-225 Rzeszów; e-mail: piotrgebica@wp.pl

** Uniwersytet Pedagogiczny im. KEN w Krakowie, ul. Podchorążych 2, 30-084 Kraków; e-mail: sl.superson@gmail.com

*** Uniwersytet Rzeszowski, Instytut Archeologii, ul. Moniuszki 10, 35-015 Rzeszów; e-mail: katarzyna.trybala@archeologia.rzeszow.pl

**** Uniwersytet Warszawski, Instytut Geologii Podstawowej, ul. Żwirki i Wigury 93, 02-089 Warszawa; email: bworonko@uw.edu.pl
} 
one na podłożu glin morenowych w wyniku wietrzenia. Praca Borowca (1974) dotyczy badań pokrywy glebowej m.in. rejonu Chotyńca i Korczowej i utworów, na których zostały one wytworzone. Autor analizując również wyniki uziarnienia (35-55\% pyłu, 30-60\% piasku i 5$15 \%$ iłu) tych osadów, doszedł do wniosku, że są to „...pyty wodnego pochodzenia stanowiace ogniwo przejściowe, między typowymi pytami centralnej części Płaskowyżu, poprzez utwory pylowe okolic Lubaczowa, aż do fluwioglacjalnych piasków, które występuja na tym obszarze" (Borowiec 1974). Utwory pyłowe rejonu Horyńca i Wielkich Oczu (przy granicy z Ukraina) były przedmiotem badań Wojtanowicza (1997). Ponadto wykonano również analizę utworów czwartorzędowych w czasie prowadzenia badań na stanowiskach archeologicznych w Kalnikowie i Chotyńcu (południowej części Płaskowyżu Tarnogrodzkiego) w sezonie 2015 i 2016 roku w ramach grantu Narodowego Centrum Nauki pt. „Przemiany kulturowo-osadnicze w dorzeczu rzeki Wiszni w epoce brązu i we wczesnej epoce żelaza w kontekście zmian prahistorycznej i wczesnohistorycznej ekumeny", kierowanego przez S. Czopka z Instytutu Archeologii Uniwersytetu Rzeszowskiego. Obejmowały one opisy odkrywek (wkopów) oraz pobór próbek do analiz laboratoryj- nych. Sporządzono także dokumentację fotograficzną stanowisk.

Celem badań prezentowanych $\mathrm{w}$ artykule była charakterystyka litologiczna osadów czwartorzędowych, na których rozlokowane są stanowiska archeologiczne w Kalnikowie i Chotyńcu. Ponadto podjęto próbę określenia genezy i wieku tych osadów, a tym samym wskazania geomorfologicznych i geologicznych czynników (uwarunkowań), jakimi mogli kierować się ludzie w czasach prehistorycznych i historycznych przy wyborze miejsca lokalizacji ich osad.

\section{Obszar badań}

Płaskowyż Tarnogrodzki położony jest w południowo-wschodniej części Kotliny Sandomierskiej. Od północy jego granicę stanowi dolina rzeki Tanew, a od południa dolina rzeki Wiszni i Wysoczyzna Chyrowska. Od zachodu sąsiaduje z doliną dolnego Sanu, a na wschodzie z Roztoczem. Z południowej części Płaskowyżu został wydzielony subregion nazwany przez Wojtanowicza (1978) Płaskowyżem Lubaczowsko-Jaworowskim, którego większa część obejmuje dorzecze rzeki Wiszni na terenie Ukrainy (rys. 1).

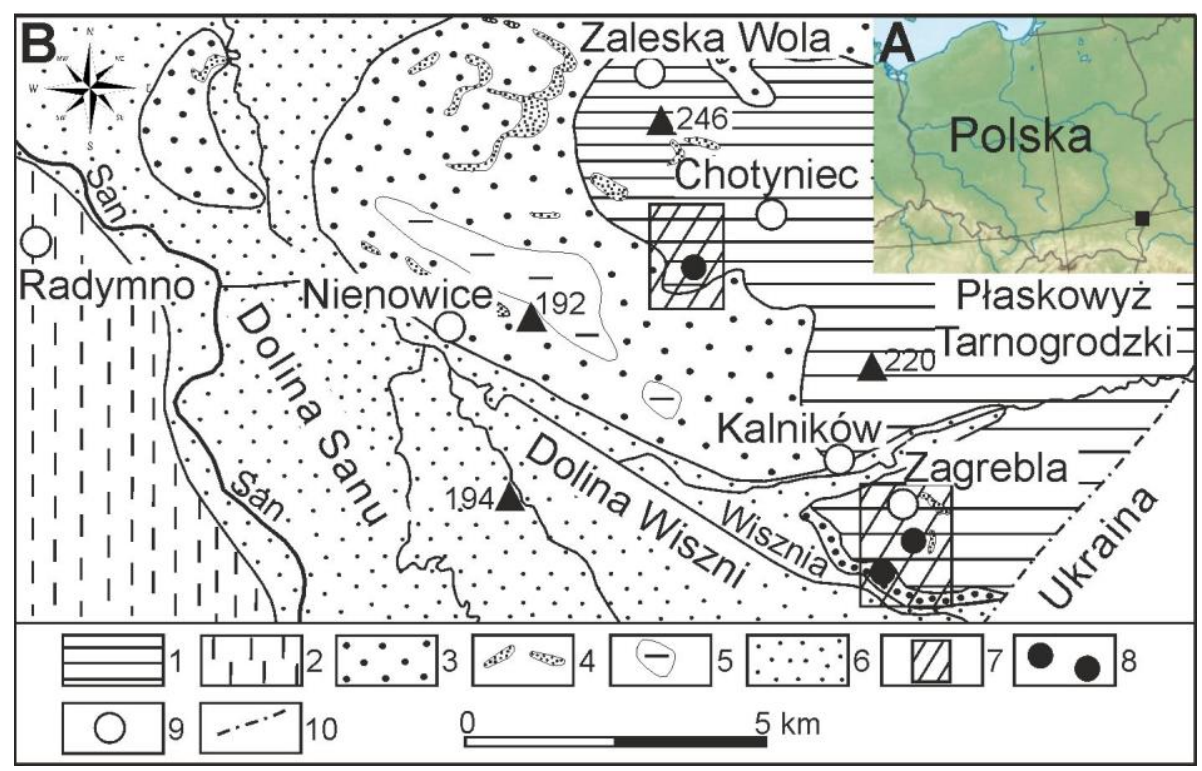

Rys. 1. Lokalizacja obszaru badań na tle mapy Polski (A) i wschodniej części Kotliny Sandomierskiej (B)

1 - wysoczyzna, 2 - terasa lessowa, 3 - terasy vistuliańska i środkowopolska (nie rozdzielone), 4 - wydmy, 5 - niecki deflacyjne, 6 - terasa zalewowa, 7 - obszar badań, 8 - lokalizacja stanowisk badawczych, 9 - miejscowości wymieniane w tekście artykułu, 10 - granica państwa

Location of the investigated area on the basis of map of Poland (A) and eastern part of Sandomierz Basin (B)

1 - plateau, 2 - loess terrace, 3 - Vistulian and Warthanian (Saalian) terraces (non divided), 4 - dunes, 5 - deflation depressions, 6 - floodplain terrace, 7 - study area, 8 - location of study sites, 9 - localities mentioned in the article, 10 - state boundary 
Południowy skraj Płaskowyżu, między dolinami rzek Szkła i Wiszni nazwany Garbem Krakowieckim (Starkel 1972), rozcięty jest dolinami ich dopływów i dolinami denudacyjnymi na szereg garbów o równinnej powierzchni wierzchowinowej i ostańców w formie stoliw wznoszących się na wysokość od 206 do 245 m n.p.m. (najwyższe wzniesienie znajduje się między wsiami Kalników a Korczowa). Na opisywanym terenie wysokości względne dochodzą do około $30 \mathrm{~m}$, najniższy punkt leży w dnie doliny Wiszni na wysokości 177 m n.p.m., a kulminacja sięga 206 m n.p.m. i znajduje się na terenie stanowiska archeologicznego Chotyniec. Garby międzydolinne, których budowę można prześledzić w zboczach dolin, budują gliny zwałowe i piaski wodnolodowcowe, a na samej powierzchni lokalnie występują utwory pylaste. Utwory czwartorzędowe o miąższości 5-10 m (maksymalnie do $20 \mathrm{~m}$ ) spoczywają na mioceńskich iłach krakowieckich (Wójcik 2002, 2008). Dopływy Wiszni o długości od 10 do $15 \mathrm{~km}$ płyną głębokimi na 20-30 m dolinami, o generalnym przebiegu z NE na SW.

W dnie doliny Wiszni i większych jej dopływów, ponad równiną zalewową wznosi się poziom terasy vistuliańskiej o wysokości 6-8 m, miejscami pokryty wydmami. Budowa i geneza osadów piaszczystych tej terasy jest dotychczas słabo poznana. Na Szczegółowej mapie geologicznej Polski, arkusz Krakowiec (1009) przypisano jej wiek korelowany ze zlodowaceniem środkowopolskim (Wójcik 2008).

Na południowych i zachodnich stokach garbów Płaskowyżu Tarnogrodzkiego występuje kilka piaszczystych poziomów z wydmami, natomiast stoki północne i wierzchowinę otulają utwory pylaste opisywane, jako lessy lub osady stokowe (Starkel 1972; Wojtanowicz 1997). Wydmy o wysokości od 2-3 m do 15 metrów mają ramiona o długości od kilkudziesięciu metrów do ponad $1 \mathrm{~km}$ (Zieliński, Semeniuk 2008). Wśród nich można wyróżnić wydmy paraboliczne $\mathrm{z}$ ramionami zwróconymi $\mathrm{w}$ kierunku $\mathrm{za}-$ chodnim, łagodnym stokiem dowietrznym i bardziej stromym stokiem zawietrznym (Zaleska Wola na NW od Chotyńca) i mniejsze formy wałowe o wysokości 3-4 m i nieznacznie zaznaczonej asymetrii stoków (stanowiska KalnikówZagrebla, Arłamowska Wola i Nienowice). Podłużne wały piasków wydmowych o wysokości kilku metrów pojawiają się również na terasie nadzalewowej Wiszni. W sąsiedztwie wydm występują niecki deflacyjne. Buraczyński (1994) analizując mapę rozmieszczenia wydm w Kotlinie Sandomierskiej, wyróżnił trzy równoleżni- kowe strefy (pasy) ich występowania. Pas południowy ciągów wydmowych obejmuje m.in. Płaskowyż Tarnogrodzki z szerokimi równoleżnikowymi dolinami, które stanowiły strefę wywiewania i transportu piasków ku wschodowi w kierunku Roztocza.

\section{Metody badań}

Badania strukturalne i teksturalne osadów zostały wykonane $\mathrm{w}$ profilach zlokalizowanych na przekroju prostopadłym do doliny Wiszni, obejmującym równinę zalewową, terasę vistuliańską oraz rozciągający się powyżej terasy stok garbu, którego kulminacja wznosi się na wysokości $202 \mathrm{~m}$ n.p.m. (rys. 2, 3). Ze wszystkich profili zlokalizowanych w pobliżu stanowisk archeologicznych w Kalnikowie i Chotyńcu (rys. 1,2) zostały pobrane próbki do analizy uziarnienia i obróbki powierz-

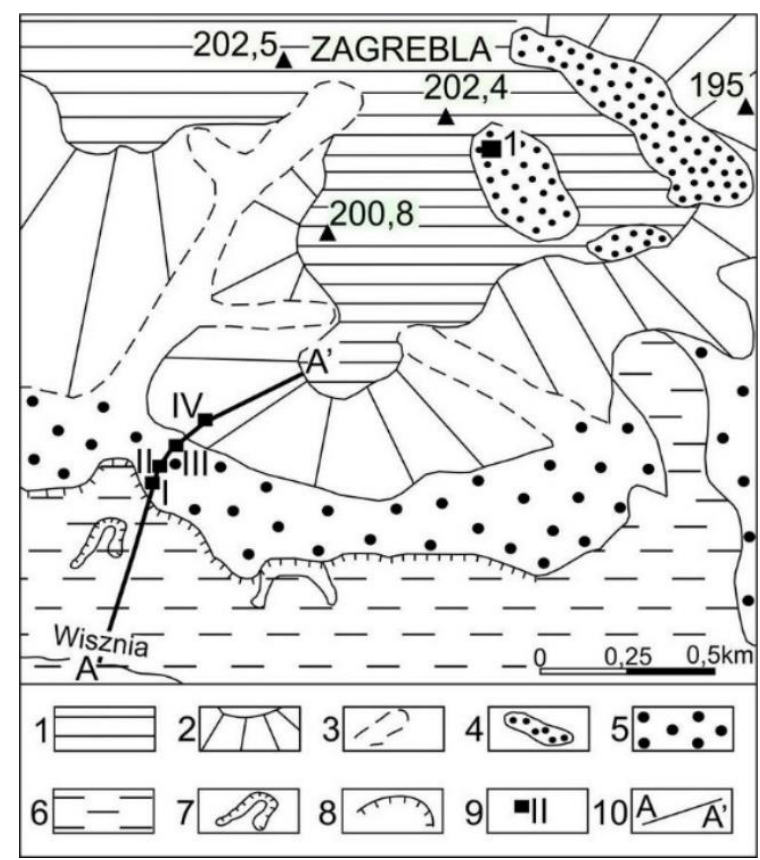

Rys. 2. Szkic geomorfologiczny analizowanych profili na stanowiskach archeologicznych w Kalnikowie-Zagrebli

1 - płaska powierzchnia wysoczyzny, 2 - skłon wysoczyzny, 3 - dolinki nieckowate (denudacyjne), 4 - wydmy, 5 terasa vistuliańska, 6 - równina zalewowa, 7 - starorzecze, 8 - krawędź (podcięcie) erozyjne, 9 - stanowiska (z numeracją profili), 10 - linia przekroju geologicznego

Geomorphological sketch of the analysed profiles in the Kalników-Zagrebla archaeological sites

1 - flat surface of plateau, 2 - slope of plateau, 3 - denudational troughs on slope, 4 -dunes, 5 - Vistulian terrace, 6 floodplain, 7 - oxbow-lakes, 8 - erosional scarp (undercut), 9 - sites with number of profiles, 10 - line of geological cross-section 


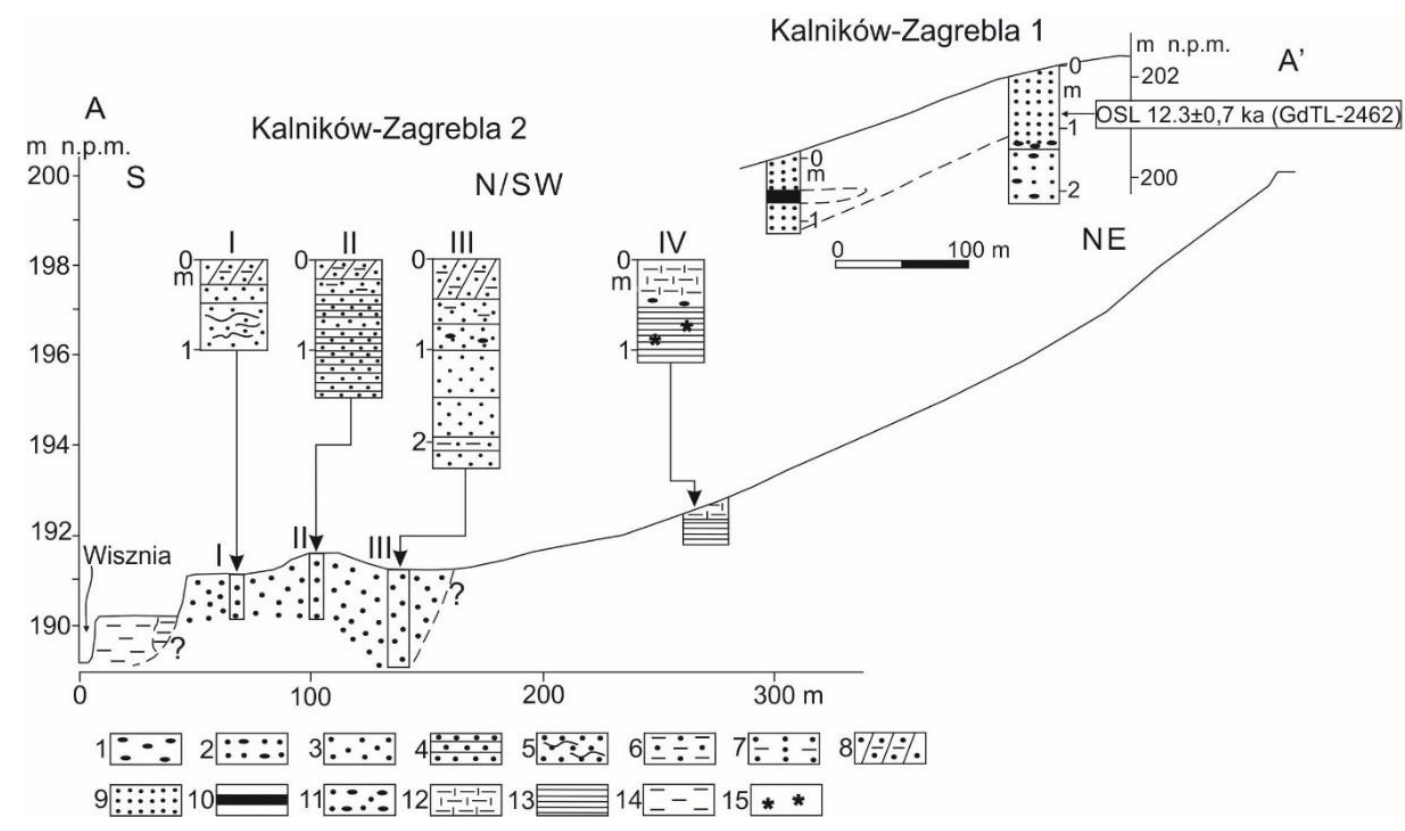

Rys. 3. Położenie opisywanych profili w Kalnikowie-Zagrebli na przekroju terasy vistuliańskiej Wiszni i skłonu wysoczyzny (lokalizacja przekroju pokazana na rys. 2)

1 - bruk żwirowy, 2 - piasek ze żwirami, 3 - piasek masywny, 4 - piasek warstwowany horyzontalnie, 5 - piasek z warstewkami orsztynu, 6 - mułek piaszczysty, 7 - piasek pylasty, 8 - gleba piaszczysta, 9 - piasek wydmowy, 10 - gleba kopalna, 11 - bruk żwirowy, 12 - pył ilasty zwietrzały, 13 - ił laminowany, 14 - mułek pozakorytowy, 15 - konkrecje węglanowe

Location of described profiles in Kalników-Zagrebla sites across the Vistulian terrace in Wisznia valley and slope of plateau (location of cross-section line see Fig. 2)

1 - gravel pavement, 2 - sand with gravel, 3 - sand with massive structure, 4 - horizontally bedded sand, 5 - sand with ferrugions laminae, 6 - sandy mud, 7 - silty sand, 8 - sandy soil, 9 - sand dune, 10 - fossil soil, 11 - gravel pavement, 12 - clayey silt weathered, 13 - laminated clay, 14 - overbank mud, 15 - calcerous concretions

chni ziaren kwarcu frakcji $0,8-1,0$ lub $0,5-0,8$ mm według analizy Cailleux (1942) w modyfikacji Mycielskiej-Dowgiałło oraz Woronko (1998). Do ostatniej analizy pobrano 12 próbek, ale w związku z bardzo drobnoziarnistym charakterem osadów i brakiem frekwencji ziarn w obu wymaganych frakcjach, jedynie jedna próbka została przebadana.

Dla próbek osadów piaszczystych wykonano analizę uziarnienia metodą sitową na sucho w zakresie frakcji 0,063-2,0 mm, wykorzystując sita co 0,5 phi, w Laboratorium Gleboznawstwa Katedry Geografii Wyższej Szkoły Informatyki i Zarządzania w Rzeszowie. Próbki osadów pylastych z profilu w Chotyńcu, w związku z ich bardzo drobnoziarnistym charakterem, poddano analizie uziarnienia metodą laserową w Laboratorium Zakładu Geomorfologii Instytutu Geografii i Gospodarki Przestrzennej UJ w Krakowie. Na podstawie uzyskanych wyników wyznaczono wartości parametrów statystycznych wyrażonych $\mathrm{w}$ jednostkach phi, tj. średniej średnicy ziarn $(\mathrm{Mz})$, wysortowania $\left(\delta_{\mathrm{I}}\right)$, skośności (Sk) i kurtozy $\left(\mathrm{K}_{\mathrm{G}}\right)$ według wzorów Folka i Warda (1957). Wszystkie parametry zostały wyliczone za pomocą programu komputerowego Gradistat (wersja $5.11 \mathrm{pl}$ ). Badania strukturalne polegały na opisie wyróżnionych w odsłonięciach warstw utworów, ich ułożenia, miąższości i charakteru granic sedymentacyjnych. Opisy cech strukturalnych i teksturalnych osadów zostały zamieszczone w tabelach.

Ponadto z profilu Kalników-Zagrebla 1 pobrano jedną próbkę osadów do datowania metodą OSL. Wiek tej próbki wyznaczono metodą OSL-SAR (pojedynczych naważek) w Laboratorium Datowania Luminescencyjnego Zakładu Zastosowań Radioizotopów Instytutu Fizyki Politechniki Śląskiej w Gliwicach. Zawartość promieniotwórczości w utworach wyznaczono metodą spektrometrii gamma i na tej podstawie określono wartości dawki rocznej - w Gy na tysiąc lat, biorąc pod uwagę wilgotność osadu, uziarnienie ziarn kwarcu, wytrawienie zewnętrznej warstwy ziarn i dawkę promieniowania kosmicznego (Adamiec, Aitken 1998). Liczba naważek ziarn kwarcu o frakcji 90-125 $\mu \mathrm{m}$, które poddano pomiarom $\mathrm{w}$ automatycznym czytniku OSL Daybreak 2200 wynosiła 14. Wartość dawki równoważnej użytej do obliczenia wieku OSL 
osadu ustalono według modelu wieku minimalnego (MAM - Galbraith i in. 1999). Wiek OSL próbki wyrażono $\mathrm{w}$ tysiącach lat przed rokiem 1950.

\section{Charakterystyka stanowisk i wyniki analiz}

\section{Stanowisko Kalników-Zagrebla 2}

Stanowisko archeologiczne zlokalizowane jest w Kalnikowie, miejscowości położonej około $15 \mathrm{~km}$ na południowy wschód od Radymna (rys. 1). W starorzeczu rzeki Wiszni, podcinającej terasę vistuliańską, na głębokości $0,5 \mathrm{~m}$ w iłach pozakorytowych, odkryto fragmenty ceramiki datowanej przez Sylwestra Czopka na epokę brązu. W trakcie archeologicznych badań wykopaliskowych na terasie vistuliańskiej założono dwa wykopy o wymiarach $2,5 \times 10 \mathrm{~m}$ i głębokości 1-1,3 m oraz trzeci, o charakterze sondażowym, o wymiarach $1 \times 50 \mathrm{~m}$ i głębokości około $1 \mathrm{~m}$ (rys. 2). Wykonano również badania na stoku wzniesienia, w obrębie którego znajduje się stanowisko, gdzie założono kolejny, niewielki wykop (wymiary: $2 \times 5 \mathrm{~m}$ i głębokości 0,7 $\mathrm{m})$. Niestety, w trakcie eksploracji nie natrafiono na archeologiczne obiekty nieruchome (np. ślady osad mieszkalnych), jedynie w wykopie sondażowym zidentyfikowano pozostałości działań związanych z I wojną światową. Były to struktury o dość regularnych zarysach, z reguły okrąłe lub owalne, $\mathrm{z}$ charakterystycznym rdzawym wypełniskiem. Pozyskano jednak materiał zabytkowy (głównie fragmenty ceramiki oraz krzemienie łączące się $\mathrm{z}$ okresem pradziejowym), który można datować na okres pomiędzy IV tysiącleciem p.n.e. a IV stuleciem p.n.e. (od neolitu, poprzez epokę brązu, aż do wczesnej epoki żelaza), a także kilkadziesiąt fragmentów ceramiki datowanych już na okres nowożytny.

Budowę terasy vistuliańskiej rozpoznano w trzech profilach wykonanych $\mathrm{w}$ odkrywkach (I-III), z których jeden został wykonany w pobliżu krawędzi terasy, następne dwa w jej środkowej i dystalnej części (rys. 2, 3). Profil Kalników-Zagrebla 2-I umiejscowiono około $20 \mathrm{~m}$ na $\mathrm{N}$ od krawędzi terasy, w kierunku wału przykorytowego (rys. 3, tab. 1).

Środkowa część terasy nadbudowana jest osadami naturalnego wału przykorytowego, w który wcięte są rowy (okopy) z okresu I wojny światowej, wypełnione szarym materiałem próchnicznym (fot. 1). Profil Kalników-Zagrebla 2-II umiejscowiono $37 \mathrm{~m}$ na północ od profilu I, w środkowej części terasy vistuliańskiej, na kulminacji wału przykorytowego między dwoma wkopami w kształcie klina, będącymi pozostałościami po obiektach kulturowych z I wojny światowej (rys. 2, 3). Tą część terasy buduje piasek drobnoziarnisty miąższości $1,45 \mathrm{~m}$ laminowany horyzontalnie i przewarstwiony osadem piaszczystym o masywnej strukturze (tab. 2).

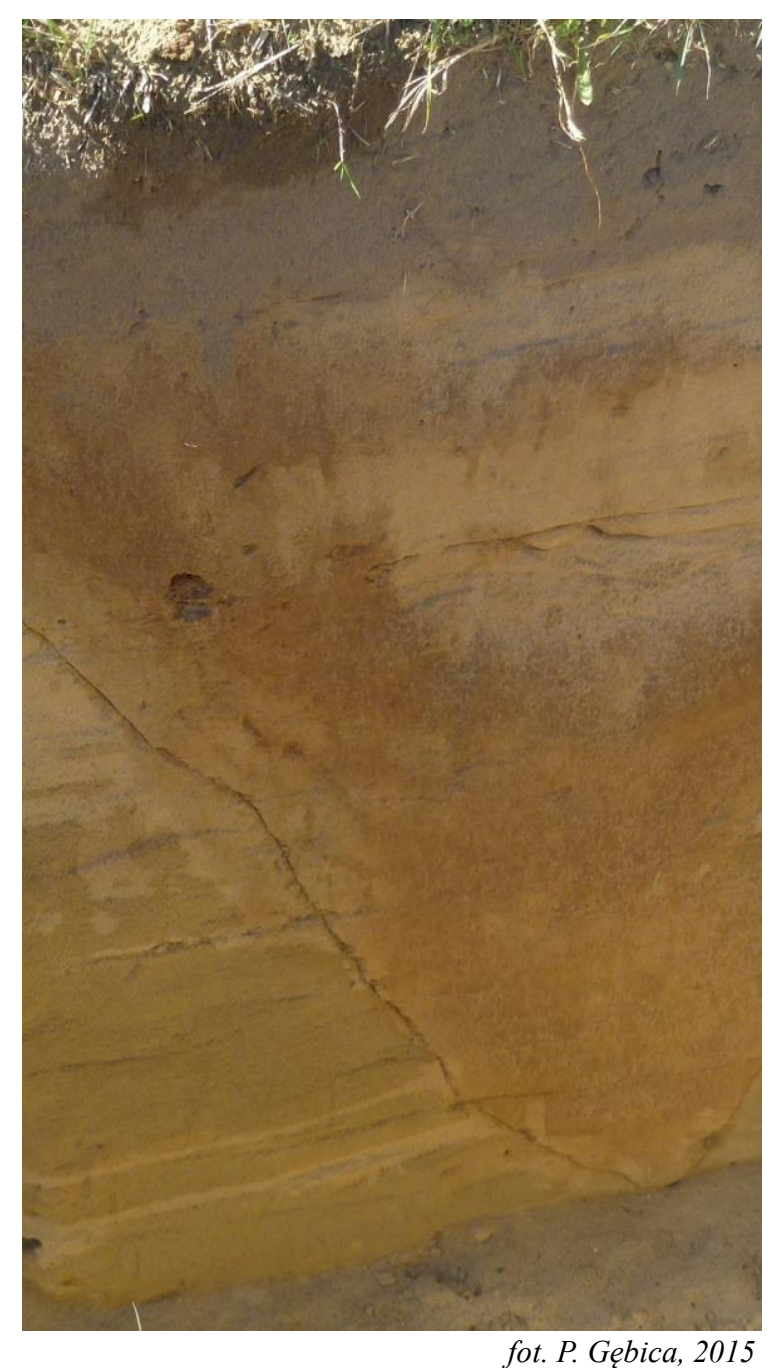

Fot. 1. Stanowisko Kalników-Zagrebla 2-II.

Piaski laminowane horyzontalnie terasy vistuliańskiej Wiszni z pozostałościami obiektów z I wojny światowej

Kalników-Zagrebla 2-II. Horizontally laminated sands of Vistulian terrace of Wisznia river with remnants of object from the I World War 
Litologia osadów w profilu Kalników-Zagrebla 2-I

Lithology of sediments in the Kalników-Zagrebla 2-I profile

\begin{tabular}{|l|c|l|}
\hline $\begin{array}{l}\text { L.p. } \\
\text { Order number }\end{array}$ & $\begin{array}{c}\text { Głębokość }(\mathrm{m}) \\
\text { Depth }(\mathrm{m})\end{array}$ & $\begin{array}{l}\text { Litologia i struktura osadów } \\
\text { Lithology and structure of deposits }\end{array}$ \\
\hline 1. & $0,00-0,12$ & warstwa humusowa z korzeniami roślin \\
\hline 2. & $0,12-0,47$ & $\begin{array}{l}\text { piasek pylasty o strukturze masywnej z korzeniami roślin, w górnej części } \\
\text { niewyraźnie laminowany, podkreślony obecnością lamin pylastych } \\
\text { i drobnopiaszczystych, koloru brązowo popielatego, }\end{array}$ \\
\hline 3. & $0,47-0,96$ & $\begin{array}{l}\text { piasek drobnoziarnisty o zmiennej miąższości i laminacji horyzontalnej } \\
\text { podkreślonej wytrąceniami związków żelaza, żółtoszary }\end{array}$ \\
\hline
\end{tabular}

Litologia osadów w profilu Kalników-Zagrebla 2-II

Lithology of sediments in the Kalników-Zagrebla 2-II

\begin{tabular}{|l|c|l|}
\hline $\begin{array}{l}\text { L.p. } \\
\text { Order number }\end{array}$ & $\begin{array}{c}\text { Głębokość }(\mathrm{m}) \\
\text { Depth }(\mathrm{m})\end{array}$ & $\begin{array}{l}\text { Litologia i struktura osadów } \\
\text { Lithology and structure of deposits }\end{array}$ \\
\hline 1. & $0,00-0,21$ & $\begin{array}{l}\text { piasek pylasty z rozproszoną materią organiczną i fragmentami korzeni } \\
\text { roślin }\end{array}$ \\
\hline 2. & $0,21-0,40$ & piasek pylasty szarożółty, w stropie wzbogacony w konkrecje węglanowe \\
\hline 3. & $0,40-0,58$ & piasek drobnoziarnisty laminowany horyzontalnie \\
\hline 4. & $0,58-0,61$ & $\begin{array}{l}\text { piasek drobnoziarnisty o strukturze masywnej z wkładkami o kształcie } \\
\text { nieregularnym piasku średnioziarnistego }\end{array}$ \\
\hline 5. & $0,61-0,72$ & piasek drobny o laminacji horyzontalnej kolorze popielato żółtym \\
\hline 6. & $0,72-0,90$ & $\begin{array}{l}\text { piasek o laminacji horyzontalnej, gdzie laminy tworzy piasek drobno- } \\
\text { i średnioziarnisty; miąższość laminy wynosi 2-3 mm }\end{array}$ \\
\hline 7. & $0,90-0,93$ & piasek pylasty o strukturze masywnej \\
\hline 8. & $0,93-1,09$ & piasek drobnoziarnisty laminowany horyzontalnie \\
\hline 9. & $1,09-1,45$ & piasek różnoziarnisty o strukturze masywnej \\
\hline 10. & $1,12-1,45$ & $\begin{array}{l}\text { piasek różnoziarnisty o warstwowany horyzontalnie, z wytrąceniami } \\
\text { węglanów }\end{array}$ \\
\hline
\end{tabular}

Analizy uziarnienia ośmiu próbek pobranych z tego profilu wskazują, że jest to piasek drobnoi bardzo drobnoziarnisty. Średnia średnica ziarna (Mz) zmienia się w przedziale od 2,42 do 2,82 phi (rys. 4, tab. 3). Wysortowanie osadów jest dobre i umiarkowanie dobre (od 0,55 do 0,77 phi). W stropowej części profilu (na głębokości 0,0 $0,40 \mathrm{~m}$ ) osad charakteryzuje ujemna skośność (od $-0,02$ do $-0,08$ phi), po czym w głąb profilu zmienia się na dodatnią $(0,03-0,07 \mathrm{phi})$. W składzie uziarnienia wszystkich próbek zaznacza się przewaga piasku drobnoziarnistego (51-65\%) i bardzo drobnoziarnistego (18-36\%). Zanotowano zróżnicowaną zawartość piasku średnioziarnistego (2,7-24 \%), najwyższą w próbce $\mathrm{nr} 5$ (rys. 4, tab. 3), co wiąże się ze słabszym wysortowaniem tej próbki i zwiększoną średnią średnicą ziarna (Mz).
Trzeci z profili Kalników-Zagrebla 2-III ulokowano $31 \mathrm{~m}$ na północ od profilu II, w dystalnej części terasy (rys. 2, 3). Tę część terasy budują osady o największym zróżnicowaniu zarówno pod względem uziarnienia, jak i struktury. Osad drobnopiaszczysty nadbudowuje materiał piaszczysto-ilasty (na głębokości 1,91-2,08 m), w którym obserwuje się zaburzenia o charakterze inwolucji (tab. 4).

\section{Kalników-Zagrebla 2-IV}

Powyżej terasy ciągnie się długi stok, który na wysokości $202 \mathrm{~m}$ n.p.m. przechodzi w płaską wysoczyznę. Na jej stoku, w odległości $135 \mathrm{~m}$ od profilu Zagrebla-Kalników 2-III, odsłaniają się zwietrzałe iły laminowane horyzontalnie. Miąższość lamin wynosi $0,5-1 \mathrm{~cm}$ i w ich obrębie 
$n$
$\frac{\pi}{0}$
$\frac{\pi}{4}$
$\frac{\pi}{4}$

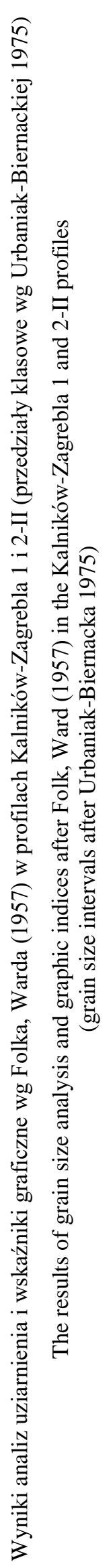

(Dy) Sisol.1ny

('Y) ezol.tny

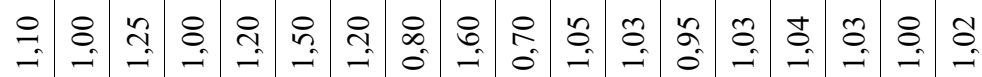

(yS) sรวимวyS

(YS) פ̦ șouşoyS

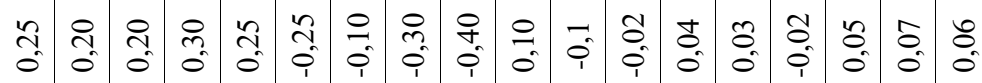

(IQ) วәиљор ви!џно

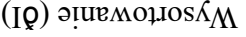

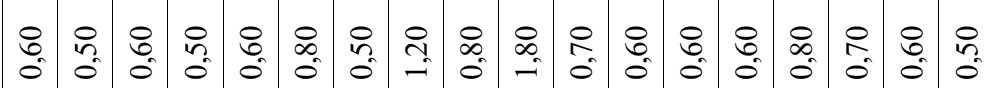

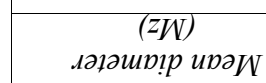

(ZW)

kọ̣upəıș p!̣upə.ıS

(wu)

(uw)
$\varepsilon 90^{\circ} 0>$

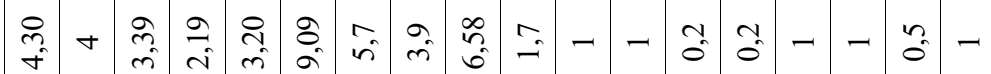

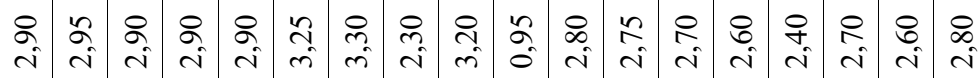

(uu)

$\varepsilon 90^{\circ} 0^{\circ}$ ऽZI $I^{\circ} 0$

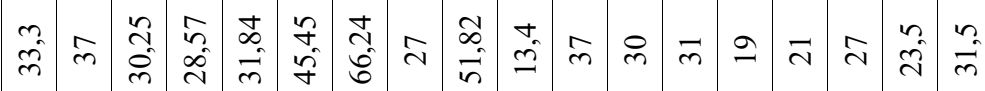

(uw)

$\varsigma Z I^{6} 0-\varsigma Z^{6} 0$

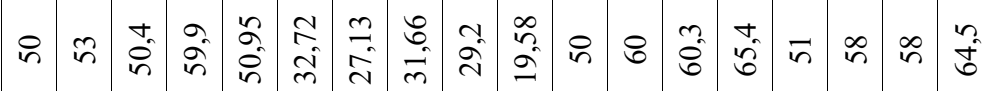

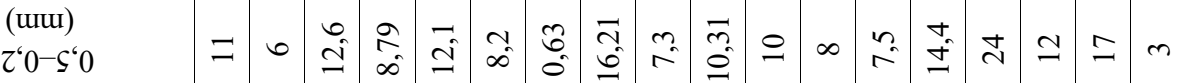

(um)

$\varsigma^{6} 0-0^{6} Z$

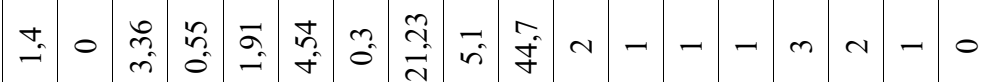

(uw)

$0^{6} \mathrm{r}<$

\begin{tabular}{llllllllllll|l|l|l|l|l|lll}
0 & 0 & 0 & 0 & 0 & 0 & 0 & 0 & 0 & $\vec{n}$ & 0 & 0 & 0 & 0 & 0 & 0 & 0 & 0
\end{tabular}

(us) $y \uparrow d \partial a$

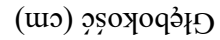

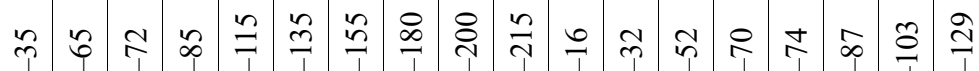

d

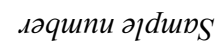

!rqo..d .IN

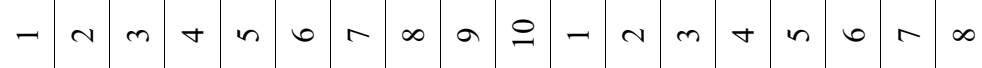




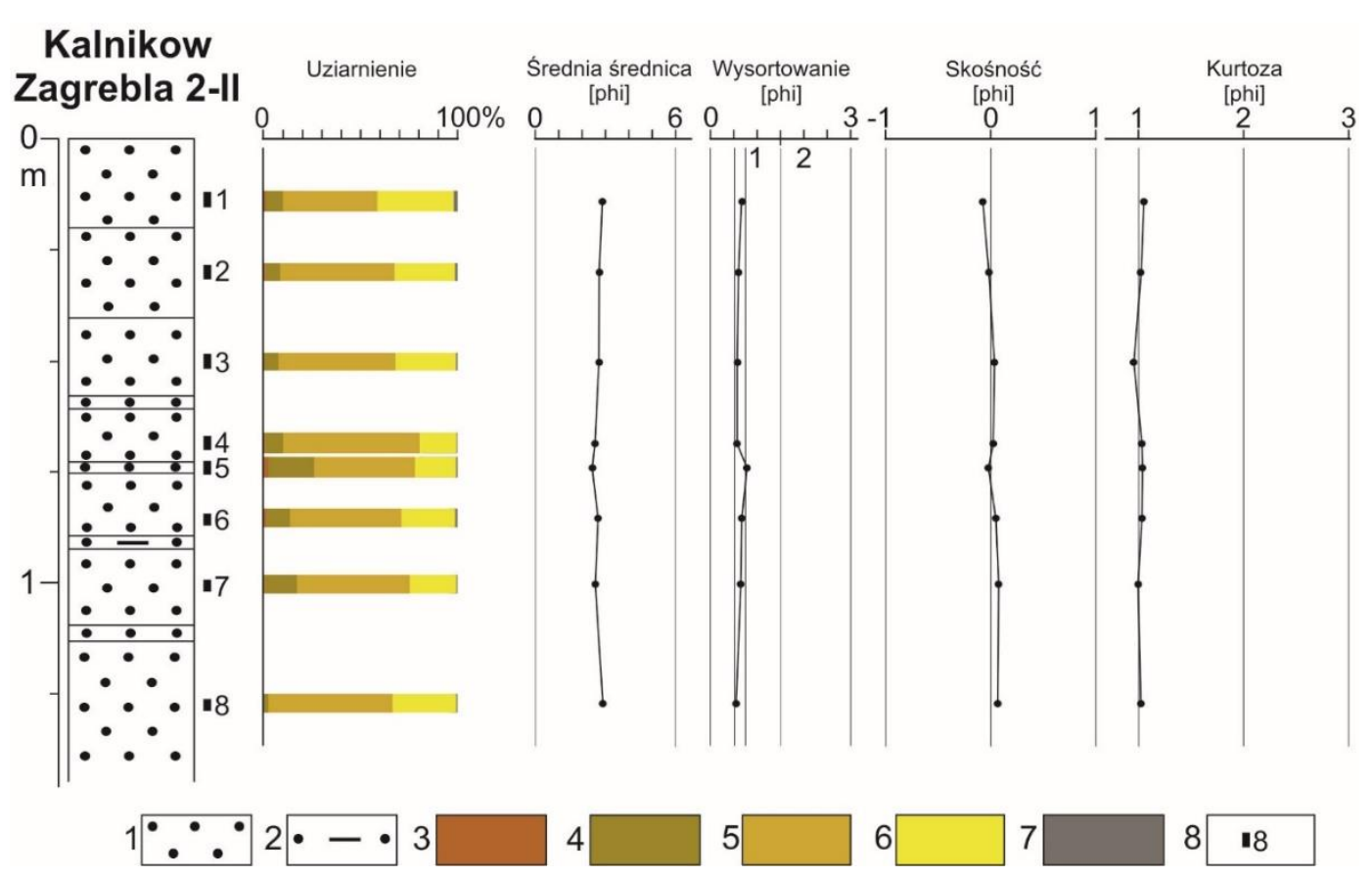

Rys. 4. Profil litologiczny (uziarnienie i wskaźniki według Folka, Warda 1957) osadów terasy vistuliańskiej w profilu Kalników-Zagrebla 2-II

1 - piasek, 2 - piasek pylasty, 3 - piasek gruboziarnisty, 4 - piasek średnioziarnisty, 5 - piasek drobnoziarnisty, 6 - piasek bardzo drobnoziarnisty, 7 - pył, 8 - lokalizacja i numer próbki na diagramie litologicznym

Lithological profile (grain size and indices after Folk, Ward 1957) of the Vistulian terrace in the Kalników-Zagrebla 2-II profile

1 - sand, 2 - silty sand, 3 - coarse sand, 4 - medium sand, 5 - fine sand, 6 - very fine sand, 7 - silt, 8 - location and sample number on the lithological diagram

Tabela 4

Litologia osadów w profilu Kalników-Zagrebla 2-III

Lithology of sediments in the Kalników-Zagrebla 2-III profile

\begin{tabular}{|l|c|l|}
\hline $\begin{array}{l}\text { L.p. } \\
\text { Order number }\end{array}$ & $\begin{array}{c}\text { Głębokość }(\mathrm{m}) \\
\text { Depth }(\mathrm{m})\end{array}$ & $\begin{array}{l}\text { Litologia i struktura osadów } \\
\text { Lithology and structure of deposits }\end{array}$ \\
\hline 1. & $0,00-0,42$ & $\begin{array}{l}\text { piasek pylasty z rozproszoną materią organiczną i fragmentami korzeni } \\
\text { roślin, koloru brązowego }\end{array}$ \\
\hline 2. & $0,42-0,71$ & $\begin{array}{l}\text { piasek pylasty koloru brązowego z wypełnionymi kanałami o średnicy } \\
\text { około 5-7 cm, powstałymi na skutek żerowania fauny glebowej (np. } \\
\text { kretów) i węgielkami }\end{array}$ \\
\hline 3. & $0,71-0,99$ & $\begin{array}{l}\text { piasek drobnoziarnisty brązowoszary o masywnej strukturze } \\
\text { z pojedynczymi żwirami średnicy kilku milimetrów }\end{array}$ \\
\hline 4. & $0,99-1,91$ & $\begin{array}{l}\text { piasek drobnoziarnisty o strukturze masywnej, koloru popielato } \\
\text { brązowego, w spągu wytrącenia Fe }{ }^{2+} \text { (pieprze) }\end{array}$ \\
\hline 5. & $1,91-2,08$ & $\begin{array}{l}\text { piasek ilasty z wytrąceniami Fe } \\
\text { smugami prasku popielatego koloru, wypełniającego pionowe struktury } \\
\text { o szerokości do 1 cm }\end{array}$ \\
\hline 6. & $2,08-2,28$ & piasek drobnoziarnisty o masywnej strukturze i popielatym kolorze \\
\hline
\end{tabular}


występują konkrecje węglanowe. Na głębokości $0,5 \mathrm{~m}$ na iłach, zalegają żwiry o średnicy $12-13$ $\mathrm{cm}$, zawierające materiał skandynawski (rys. 3). Są to prawdopodobnie żwiry rezydualne powstające wskutek denudacji osadów lodowcowych i wodnolodowcowych akumulowanych w okresie zlodowaceń południowopolskich.

\section{Stanowisko Kalników-Zagrebla 1 (stanowi- sko arch. Kalników 31 (AZP 106-86/34)}

W odległości $1 \mathrm{~km}$ na północny wschód od profilu Kalników-Zagrebla 2-IV zostało zlokalizowane stanowisko archeologiczne Kalników-Zagrebla 1 (N 4954.448', E 2302.066') (rys. 2). Jest ono położone na wysokości $202 \mathrm{~m}$ n.p.m., w nieczynnej piaskowni usytuowanej wzdłuż holwegu, rozcinającego w poprzek wał wydmowy o wysokości $2 \mathrm{~m}$ i szerokości około $20 \mathrm{~m}$. Wał rozciąga się po południowej (zawietrznej) stronie kulminacji płaskowyżu, na łagodnie nachylonym długim skłonie, opadającym do dna doliny Wiszni (rys. 2, 3). Na stanowisku nie były prowadzone badania wykopaliskowe, jednakże w obrębie piaskowni, pozyskano fragment ceramiki tarnobrzeskiej kultury łużyckiej datowany na wczesną epokę żelaza, tj. pomiędzy poł. VII a IV w. p.n.e. (Czopek 2001, 2007; Trachsel 2004). W piaskowni odsłaniają się osady o miąższości 2,20 m, w których wyraźnie zaznaczają się trzy poziomy bruków (na głębokościach: 1,3 m, 1,75-1,80 m i 2,20 m), które buduje osad grubopiaszczysty z pojedynczymi klastami żwirów, o średnicy do 5-6 cm i które przewarstwiają osady drobnopiaszczyste (tab. 5, fot. 2).

Analizę uziarnienia wykonano dla 10 próbek osadów piaszczystych. Średnia średnica ziarna $\mathrm{w}$ analizowanych próbkach zawiera się $\mathrm{w}$ przedziale 0,95-3,3 phi (rys. 5, tab. 3), co wskazuje, że jest to piasek od bardzo drobnoziarnistego (powyżej 3 phi) do gruboziarnistego (0-1 phi) (Wentworth 1922; Urbaniak-Biernacka 1975; Mycielska-Dowgiałło 2007). W stropowej części profilu (do głębokości 1,2 m) przeważa piasek drobno- i bardzo drobnoziarnisty, o umiarkowanie dobrym wysortowaniu $\left(\delta_{\mathrm{I}}=0,5-0,6 \mathrm{phi}\right)$ i dodatniej skośności $(0,2-0,3$ phi). W spągowej części profilu (poniżej 1,2 m) wzrasta udział grubszych frakcji (drobnego żwiru i piasku gruboziarnistego) i następuje zmiana skośności osadów na ujemną (-0,1-0,4 phi) (rys. 5, tab. 3).

Wyniki analizy Cailleux (1942) w modyfikacji Mycielskiej-Dowgiałło i Woronko (1998) wskazują, że w osadach żwirowych z głębokości

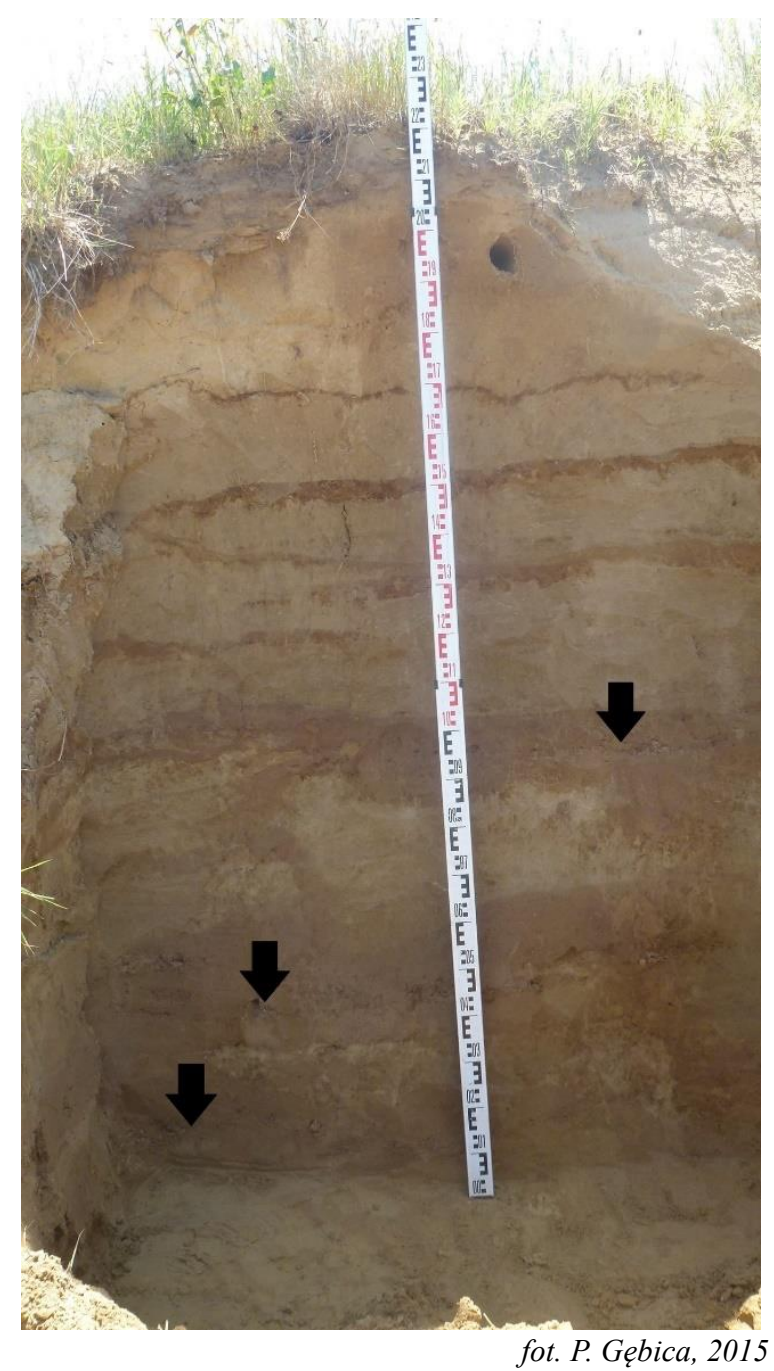

Fot. 2. Stanowisko Kalników-Zagrebla 1.

Piaski wydmowe nadbudowują osady wodnolodowcowe z trzema poziomami bruków żwirowych,

których położenie pokazano strzałkami

Kalników-Zagrebla 1. Sand dune overlies the fluvioglacial sediments with three thin gravel horizons

which location was showed by arrows

1,66-1,69 m dominują ziarna typu ,inne”, których powierzchnia jest efektem wietrzenia chemicznego, zapisanego $\mathrm{w}$ formie intensywnie trawionej powierzchni i jej oskorupienia (tab. 6). Stanowią one $53,4 \%$. W badanej próbce reprezentują duży zakres obtoczenia, od bardzo dobrego (tj. powyżej 0,7 wg skali Krumbeina (1941)), do pośredniego $(0,3-0,6)$. Wietrzenie chemiczne zatarło wcześniejszą mikrorzeźbę powierzchni ziarn. Znaczący udział mają również ziarna o pośrednim stopniu obtoczenia i matowych jedynie na najbardziej wypukłych fragmentach tj. krawędziach i narożach, typu EM/RM (24,8\%). Ich obróbka następowała $\mathrm{w}$ środowisku eolicznym. Jednakże niewielki stopień obtoczenia, wskazuje, że były poddawane transportowi 
Litologia osadów w profilu Kalników-Zagrebla 1

Lithology of sediments in the Kalników-Zagrebla 1 profile

\begin{tabular}{|l|c|l|}
\hline $\begin{array}{l}\text { L.p. } \\
\text { Order number }\end{array}$ & $\begin{array}{c}\text { Głębokość }(\mathrm{m}) \\
\text { Depth }(\mathrm{m})\end{array}$ & $\begin{array}{l}\text { Litologia i struktura osadów } \\
\text { Lithology and structure of deposits }\end{array}$ \\
\hline 1. & $0,00-0,15$ & poziom humusowy \\
\hline 2. & $0,15-1,20$ & $\begin{array}{l}\text { piasek drobnoziarnisty przewarstwiony piaskiem ilastym, o zwartej } \\
\text { i masywnej strukturze i miąższości od 1 do } 7 \mathrm{~cm}\end{array}$ \\
\hline 3. & $1,20-1,40$ & $\begin{array}{l}\text { piasek silnie zorsztynizowany, na głębokości 1,3 m poziom bruku } \\
\text { żwirowego, żwiry średnicy -4 mm do 1 cm }\end{array}$ \\
\hline 4. & $1,40-1,60$ & piasek bardzo drobnoziarnisty pylasty, żółty z żelazistymi zaciekami \\
\hline 5. & $1,60-1,90$ & $\begin{array}{l}\text { piasek średnio- i gruboziarnisty ze żwirem, na gł. 1,75-1,80 m bruk } \\
\text { żwirowy (kwarce, granity, krzemienie) średnicy 1-4 cm }\end{array}$ \\
\hline 6. & $1,90-2,00$ & piasek drobnoziarnisty o masywnej strukturze i żółtym kolorze \\
\hline 7. & $2,00-2,20$ & $\begin{array}{l}\text { piasek gruboziarnisty zażelaziony, w spągu warstwa żwiru (poziom } \\
\text { bruku) o średnicy 1-2 cm }\end{array}$ \\
\hline
\end{tabular}

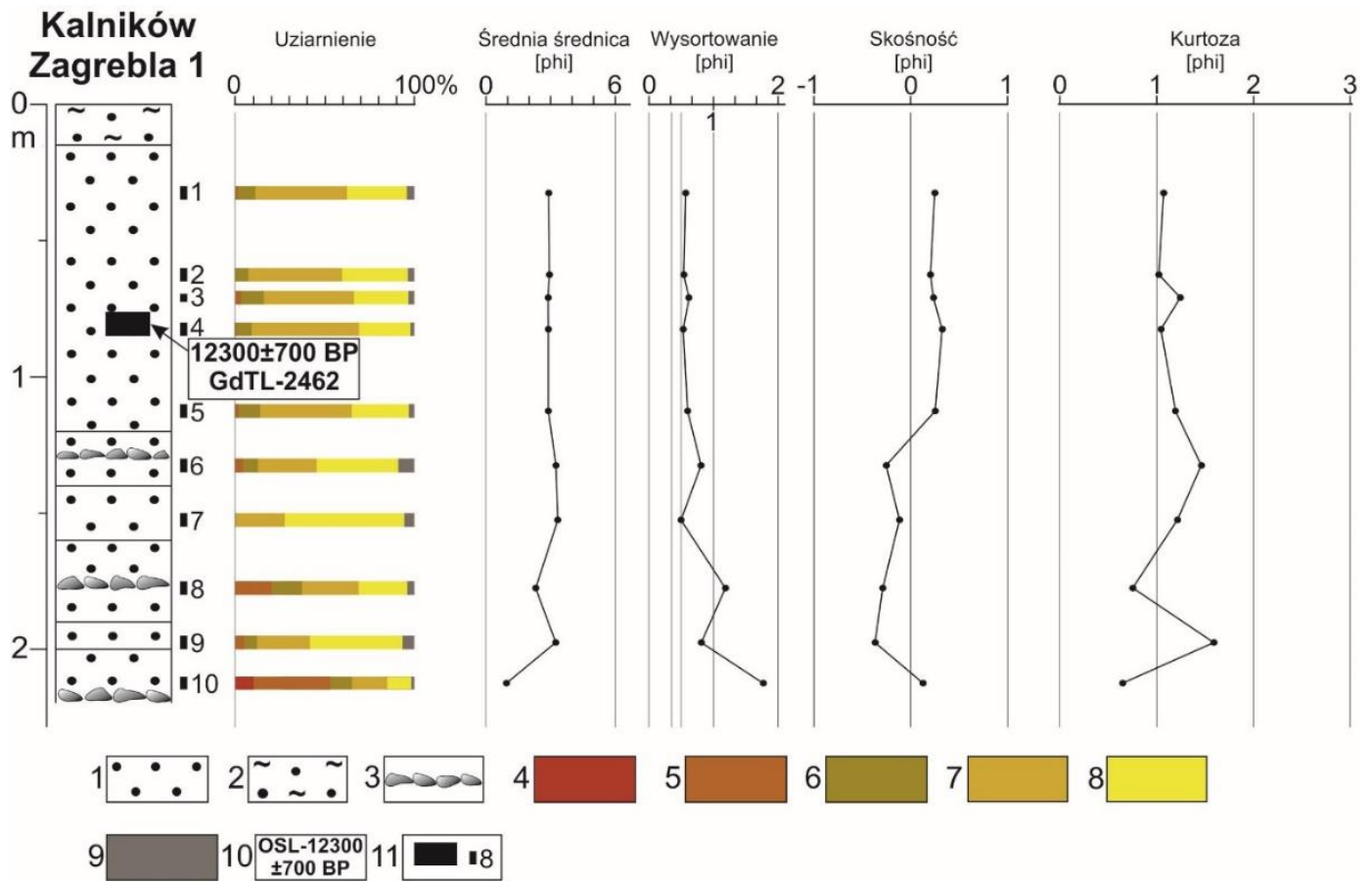

Rys. 5. Profil litologiczny (uziarnienie i wskaźniki według Folka, Warda 1957) wydmy w profilu Kalników-Zagrebla 1

1 - piasek, 2 - humus z piaskiem, 3 - bruk żwirowy, 4 - żwir drobny, 5 - piasek gruboziarnisty, 6 - piasek średnioziarnisty, 7 - piasek drobnoziarnisty, 8 - piasek bardzo drobnoziarnisty, 9 - pył, 10 - datowanie OSL i numer laboratoryjny próbki, 11 - lokalizacja i numer próbki na diagramie litologicznym

Lithological profile (grain size and indices after Folk, Ward 1957) of dune in the Kalników-Zagrebla 1 profile 1 - sand, 2 - humus with sand, 3 - gravel lag, 4 - fine gravel, 5 - coarse sand, 6 - medium sand, 7 - fine sand, 8 - very fine sand, 9 - silt, 10 - OSL dating and laboratory number of sample, 11 - location and sample number on the lithological diagram 
Wyniki analizy Cailleux (1942) w modyfikacji Mycielskiej-Dowgiałło i Woronko (1998); opis typów ziarn w tekście

Results of Cailleux (1942) analysis in the modification of Mycielska-Dowgiałło and Woronko (1998); description types of grains in the text

\begin{tabular}{|l|c|c|c|c|c|c|c|}
\hline $\begin{array}{l}\text { Typy ziarn } \\
\text { Types of grains }\end{array}$ & EL & EM/EL & RM & EM/RM & INNE & C & NU \\
\hline & $3,7 \%$ & $17,3 \%$ & $0,7 \%$ & $24,8 \%$ & $53,4 \%$ & $0,0 \%$ & $0,0 \%$ \\
\hline
\end{tabular}

W tym środowisku przez stosunkowo krótki okres (Mycielska-Dowgiałło 2001; Woronko i in. 2015). Środowisko eoliczne reprezentują również ziarna dobrze obtoczone typu RM. Jednakże udział tego typu ziarn w próbce wynosi zaledwie 0,7\%. Na podobnym poziomie, jak ziarna eoliczne, kształtuje się udział ziarn reprezentujacych środowisko wodne, zarówno o pośrednim stopniu obtoczenia EM/EL - 17,3\%, jak i bardzo dobrze obtoczonych EL - 3,7\%. Nie zanotowano ziarn pękniętych (C) oraz kanciastych o ostrych krawędziach i narożach - NU (tab. 6).

Datowanie metodą OSL piasków ze stropowej części profilu, $\mathrm{z}$ głębokości $0,8 \mathrm{~m}$ dało wynik $12300 \pm 700$ lat BP (GdTL-2462), co odpowiada młodszemu dryasowi (12,9-11,7 ka cal BP; Carlson 2013).

\section{Stanowisko Chotyniec}

Stanowisko Chotyniec położone jest $6 \mathrm{~km}$ na północny zachód od punktu Kalników-Zagrebla 1 (rys. 1). W Chotyńcu badania obejmowały fragment wysoczyzny wznoszącej się na wysokości 206 m n.p.m., na powierzchni której archeolodzy zlokalizowali, w jej południowo-wschodniej części, wał ziemny o wysokości $1,7 \mathrm{~m}$, szerokości około $30 \mathrm{~m}$ i długości $530 \mathrm{~m}$ (rys. 6, 7, fot. 3). Założenie wału należy łączyć z bardzo dużym grodziskiem, które jak wskazuje odkryty materiał zabytkowy, jest związany ze scytyjskim kręgiem kulturowym. W trakcie archeologicznych badań wykopaliskowych pogłębiono i odczyszczono istniejący wcześniej przekop przechodzący przez wał grodziska, co przede wszystkim miało na celu uzyskanie jak najpełniejszego rozpoznania jego konstrukcji oraz pozyskanie materiałów do datowań radiowęglowych. Założono również wykopy sondażowe w północnej części majdanu grodziska, gdzie natrafiono na zabytki archeologiczne (fragmenty ceramiki, brązowy grocik scytyjski, duże ilości polepy, kości zwierzęce) świadczące o tym, że są to fragmenty założenia kultowego, tzw. ,,zolnika". Całość odkrytego materiału zabytkowego

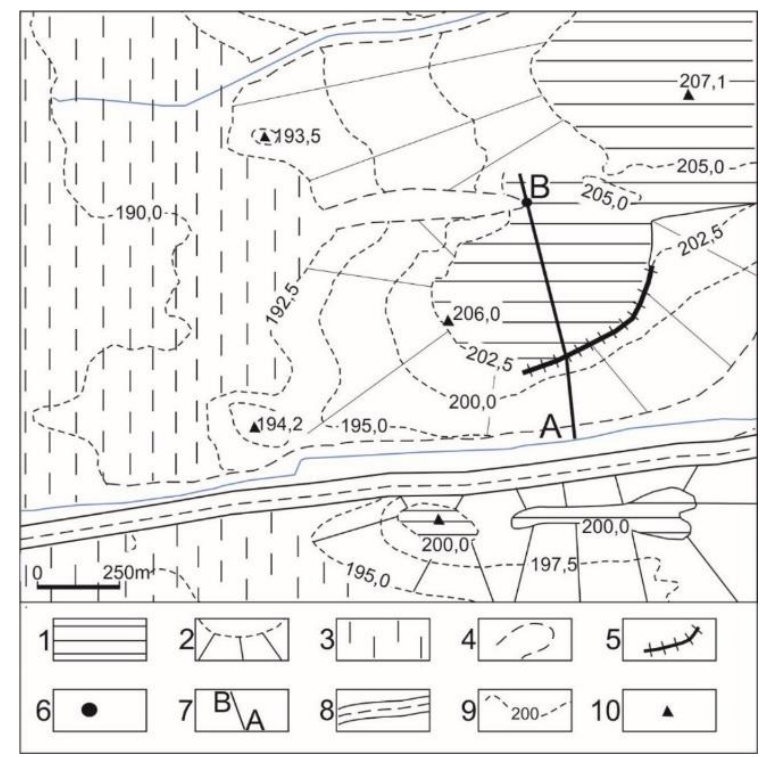

Rys. 6. Szkic geomorfologiczny otoczenia wału grodziska na stanowisku w Chotyńcu z lokalizacją badanych profili

1 - płaska powierzchnia wysoczyzny, 2 - stok wysoczyzny, 3 - podnóże wysoczyzny okryte deluwiami, 4 - dolinki denudacyjne (nieckowate), 5 - wał grodziska, 6 - stanowisko badawcze, 7 - linia przekroju geologicznego, 8 - autostrada A-4, 9 - poziomice, 10 - punkty wysokościowe

Geomorphological sketch the surrounding of the hillfort rampart in the Chotyniec site with location of studied profiles

1 - flat surface of plateau, 2 - slope of plateau, 3 - foot of plateau covered with deluvial sediments, 4 - denudational troughs on slope, 5 - hillfort rampart, 6 - study site, 7 - line of geological cross-section, 8 - highway A-4, 9 - contour lines, 10 - altitude points

należy łączyć z okresem VII-VI w. p.n.e. (Czopek $\mathrm{i}$ in. w druku). Wał grodziska (N 49 56',761; E 2259',136) zbudowany jest z trzech zróżnicowanych litologicznie warstw (rys. 7, fot. 4). W spągu nasypu na głębokości 1,4-1,7 m, najstarszą warstwę budują osady pylaste zmienione przez procesy glebotwórcze, o czym świadczy ich zażelazienie związane $\mathrm{z}$ poziomem wmycia i struktura agregatowa, nadbudowana piaskiem pylastym ze żwirkami i krzemieniami narzutowymi. Strop nasypu tworzy warstwa zwartego 


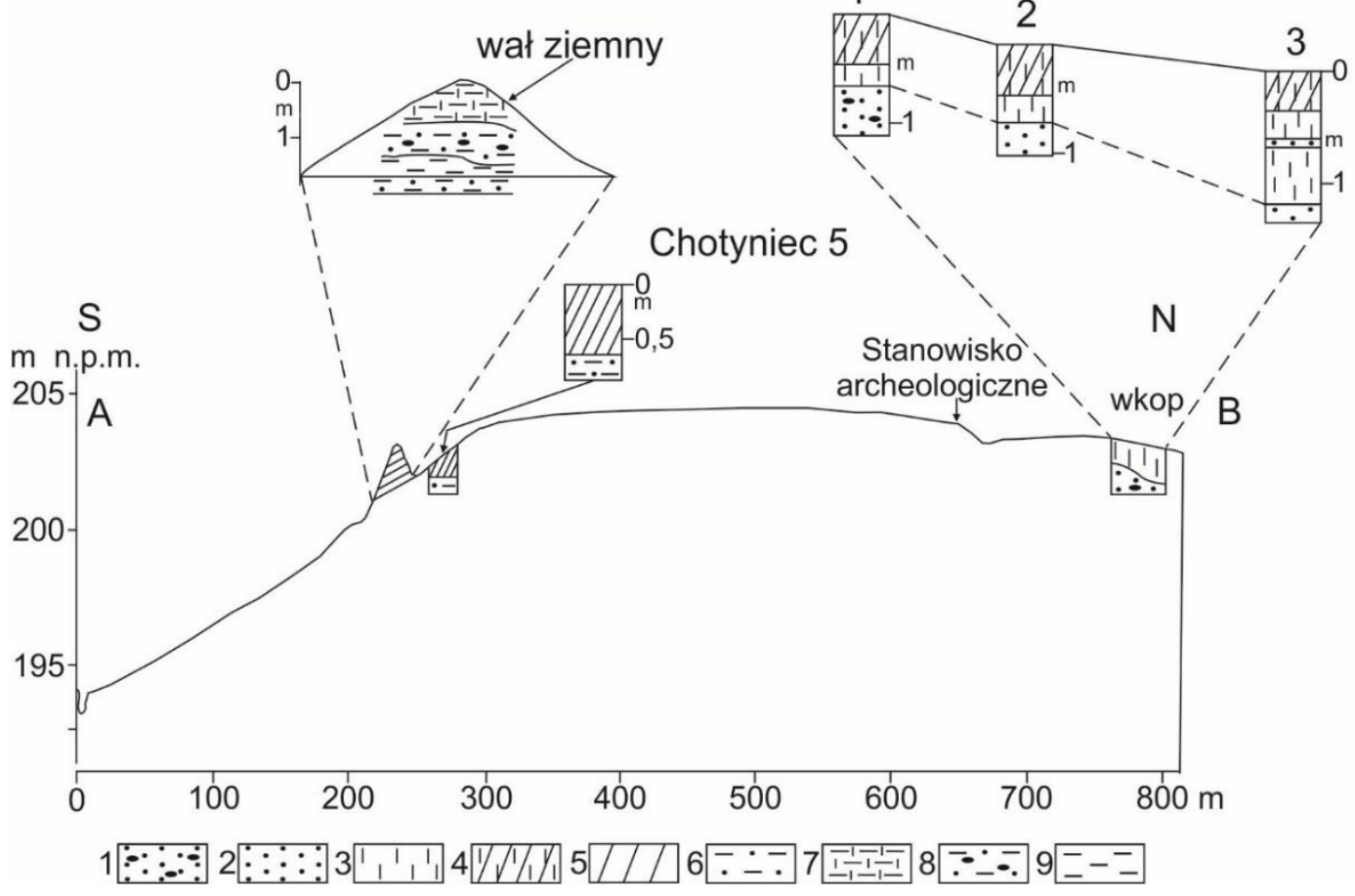

Rys. 7. Położenie i budowa analizowanych profili na przekroju stanowiska w Chotyńcu (lokalizacja przekroju patrz rys. 6)

1 - piasek ze żwirem, 2 - piasek, 3 - pył (less piaszczysty), 4 - gleba pylasta, 5 - namywy (deluwia) próchniczne, 6 - piasek pylasty, 7 - pył ilasty humusowy, 8 - pył piaszczysty ze żwirem, 9 - mułek (pył) zmieniony przez procesy glebotwórcze

Location and structure of the analysed profiles in the Chotyniec cross-section (location of cross-section see Fig. 6)

1 - sand with gravel, 2 - sand, 3 - silt (sandy loess), 4 - silty soil, 5 - deluvia, 6 - silty sand, 7 - clayey silt with humus, 8 sandy silt with gravel, 9 - mud (silt) changed by soil processes

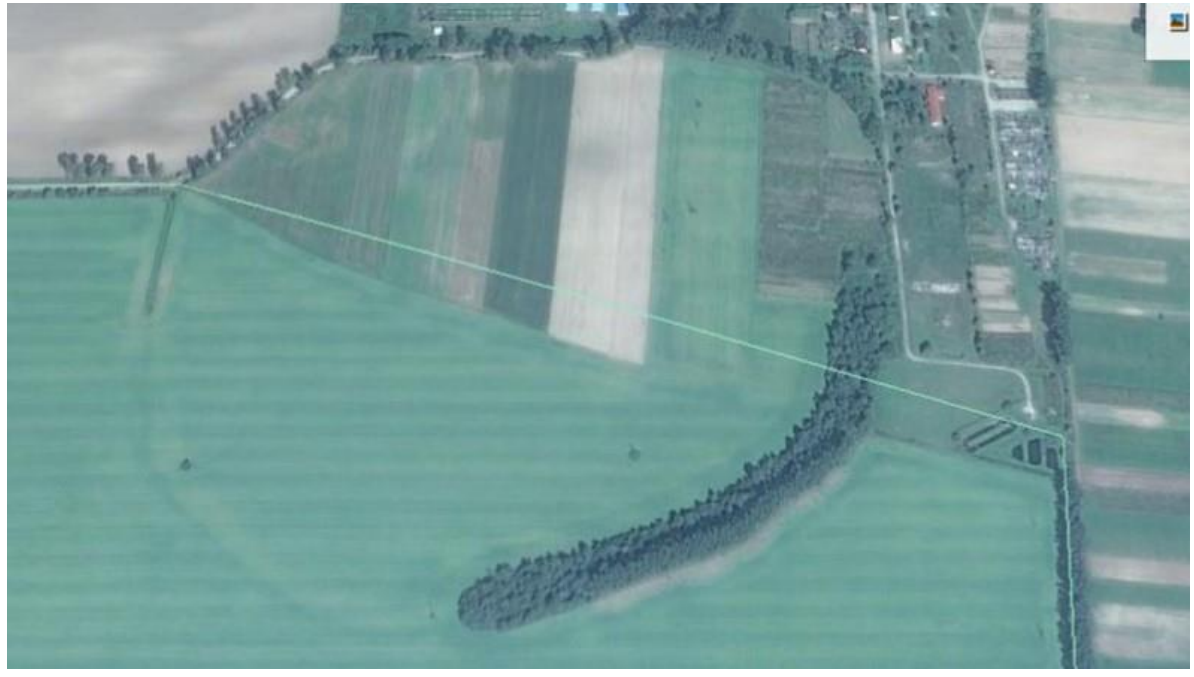

Google Earth Pro

Fot. 3. Stanowisko Chotyniec. Wał grodziska z VII-VI wieku p.n.e. otacza od południowego wschodu wierzchowinę płaskowyżu

Chotyniec site. Hillfort rampart (VII-VI c. BC) surrounding the plateau from the south-east 


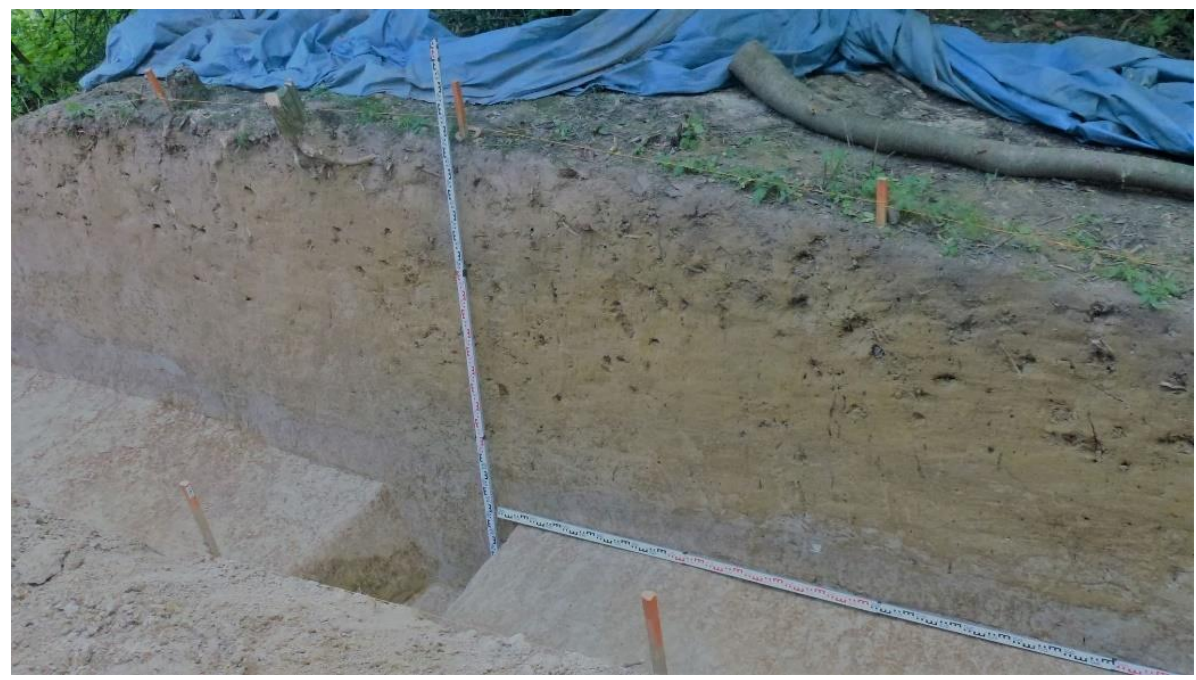

fot. P. Gębica, 2015

Fot. 4. Budowa wału grodziska w Chotyńcu odsłoniętego w czasie prac archeologicznych

The structure of hillfort rampart in the Chotyniec excavated during archaeological fieldwork

pyłu ilastego ciemnobrunatnego $\mathrm{z}$ korzeniami drzew. W podłożu wału występuje piasek pylasty popielatoszary, który został odsłonięty już poza wałem, we wkopie (N 4956',729; E 2259',005) pod warstwą namywów próchnicznych, na głębokości $0,65 \mathrm{~m}$ w jego zachodniej części. We wkopie długości $30 \mathrm{~m}$, przecinającym obecnie nieistniejący (zerodowany) wał ziemny, odsłonięto osady budujące wierzchowinę. Od strony $\mathrm{N}-\mathrm{W}$ wału budują ją utwory pylaste o barwie jasnopopielatej, strukturze masywnej i miąższości $0,6-1,2 \mathrm{~m}$ (fot. 5, rys. 6).
W profilu Chotyniec 1 (rys. 7) osady pylaste o strukturze masywnej i miąższości $0,63 \mathrm{~m}$, spoczywają na piaskach $\mathrm{z}$ nielicznymi żwirami o średnicy 1-3 cm i krzemieniami (tab. 7).

Analizy uziarnienia dowodzą, że jest to pył $\mathrm{z}$ domieszką piasku drobno- $\mathrm{i}$ średnioziarnistego, bardzo słabo wysortowany (2,63 phi), o rozkładzie symetrycznym (rys. 8, tab. 8). Wyniki pochodzące $\mathrm{z}$ tej części profilu, wskazują na duży udział piasku grubo- i średnioziarnistego (powyżej $85 \%$ ) o umiarkowanym wysortowaniu i dodatniej skośności (tab. 8).

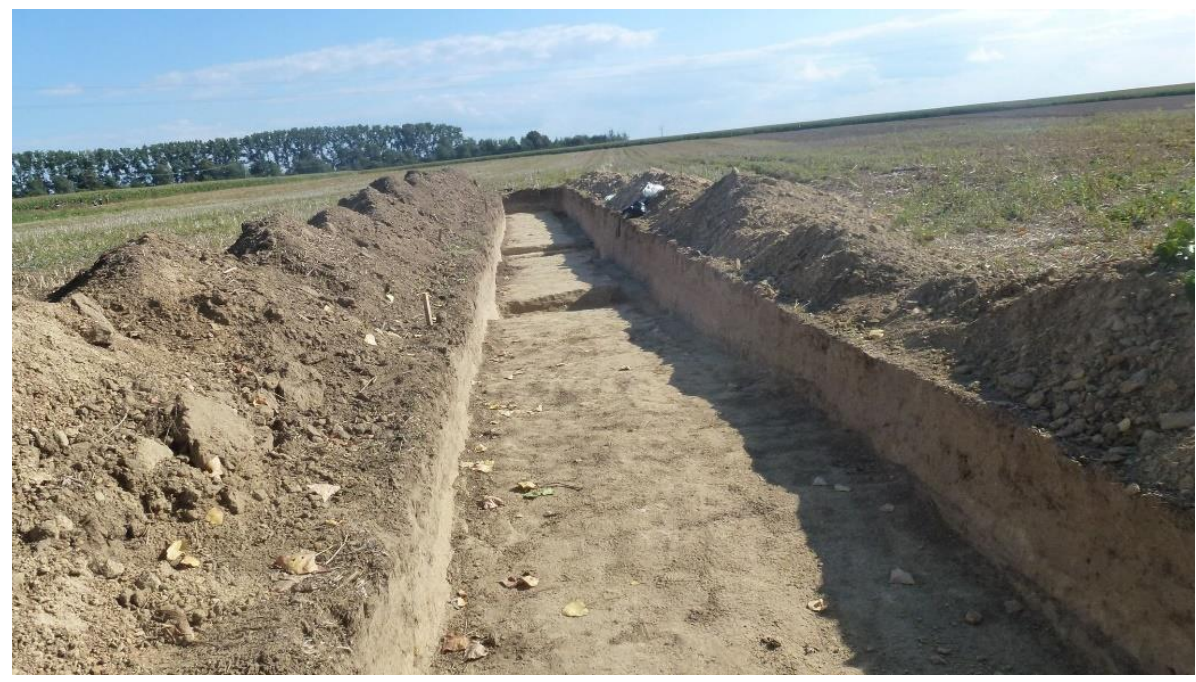

fot. P. Gębica, 2015

Fot. 5. Stanowisko Chotyniec. Przekrój pokrywy pylastej odsłonięty we wkopie długości $30 \mathrm{~m}$ w północno-zachodniej części wierzchowiny

Chotyniec site. Cross-section of the silt cover excavated in the trench 30 metres long in the north-west part of plateau 
Litologia osadów w profilu Chotyniec 1

Lithology of sediments in the Chotyniec 1 profile

\begin{tabular}{|l|c|l|}
\hline $\begin{array}{l}\text { L.p. } \\
\text { Order number }\end{array}$ & $\begin{array}{c}\text { Głębokość }(\mathrm{m}) \\
\text { Depth }(\mathrm{m})\end{array}$ & $\begin{array}{l}\text { Litologia i struktura osadów } \\
\text { Lithology and structure of deposits }\end{array}$ \\
\hline 1. & $0,00-0,37$ & pył o masywnej strukturze, jasnoszarej barwie, poziom orny gleby \\
\hline 2. & $0,37-0,63$ & pył jasnopopielaty o strukturze masywnej z węgielkami w stropie \\
\hline 3. & $0,63-1,10$ & piasek średnio- i gruboziarnisty ze żwirem o średnicy 1-3 cm \\
\hline
\end{tabular}

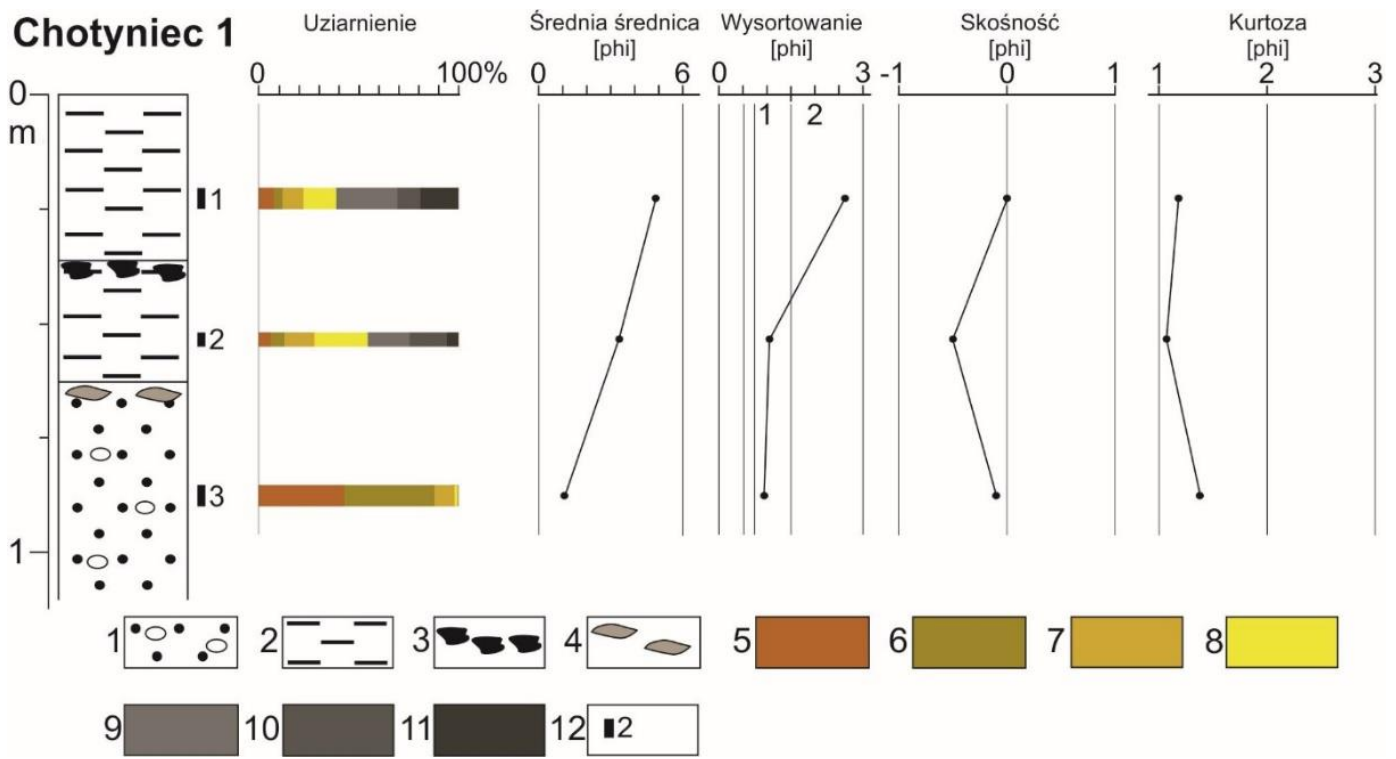

Rys. 8. Profil litologiczny (uziarnienie i wskaźniki według Folka, Warda 1957) pokrywy pyłów i osadów fluwioglacjalnych w profilu Chotyniec 1

1 - piasek ze żwirem, 2 - pył, 3 - węgle drzewne, 4 - krzemienie, 5 - piasek gruboziarnisty, 6 - piasek średnioziarnisty, 7 - piasek drobnoziarnisty, 8 - piasek bardzo drobnoziarnisty, 9 - pył gruboziarnisty, 10 - pył średnioziarnisty, 11 - pył drobnoziarnisty, 12 - lokalizacja i numer próbki na diagramie litologicznym

Lithological profile (grain size and indices after Folk, Ward 1957) silty cover and glaciofluvial sediments in the Chotyniec 1 profile

1 - sand with gravel, 2 - silt, 3 - charcoals, 4 - cherts, 5 - coarse sand, 6 - medium sand, 7 - fine sand, 8 - very fine sand, 9 - coarse silt, 10 - medium silt, 11 - fine silt, 12 - location and sample number on the lithological diagram

W profilu Chotyniec 2 (rys. 7) miąższość osadów pylastych wynosi $0,76 \mathrm{~m}$, a w profilu Chotyniec 3, zlokalizowanym $16 \mathrm{~m}$ na $\mathrm{N}$ od profilu 2, wzrasta do $1,2 \mathrm{~m}$ (rys. 7, tab. 9). Na głębokości 0,63-0,65 m stwierdzono występowanie pojedynczej laminy piasku drobnoziarnistego rozdzielającego osady pylaste (fot. 6).

Pod względem uziarnienia w osadach tych dominuje frakcja pyłowa $(0,063-0,002 \mathrm{~mm})$, której udział wynosi 52-63\% (rys. 9, tab. 8). Ziarna piasku bardzo drobnoziarnistego $(0,125-$ $0,063 \mathrm{~mm})$ stanowią $17,2-22,7 \%$, natomiast pozostała frakcja piaszczysta $(0,125-2,0 \mathrm{~mm})$, to 10-22\%. Udział frakcji iłowej (poniżej 0,002 $\mathrm{mm})$ zmienia się $\mathrm{w}$ przedziale $4-6,7 \%$. W związku z tym, utwory te można sklasyfikować, jako pyły piaszczyste. 


\begin{tabular}{|c|c|c|c|c|c|c|c|c|c|}
\hline $\begin{array}{l}\text { ('Y) s!sot.ny } \\
\text { ('Y) ezoluny }\end{array}$ & 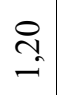 & $\begin{array}{l}\stackrel{0}{=} \\
=\end{array}$ & $\stackrel{\stackrel{P}{f}}{\rightarrow}$ & $\stackrel{0}{\cong}$ & $\stackrel{\overbrace{}}{\approx}$ & $\begin{array}{l}\infty \\
\infty \\
0\end{array}$ & $\begin{array}{l}\text { ̊̆ } \\
\text { a }\end{array}$ & $\stackrel{0}{=}$ & సิ \\
\hline $\begin{array}{l}\text { (yS) ssaumays } \\
\text { (YS) əșoușoys }\end{array}$ & $\begin{array}{l}8 \\
0 \\
0\end{array}$ & $\begin{array}{l}\text { ơ } \\
\text { ô }\end{array}$ & $\frac{0}{0}$ & $\begin{array}{l}n \\
0 \\
0\end{array}$ & $\frac{0}{0}$ & $\begin{array}{l}\stackrel{1}{1} \\
\text { ô }\end{array}$ & $\stackrel{n}{2}$ & ڤે & $\begin{array}{l}\text { J } \\
0\end{array}$ \\
\hline 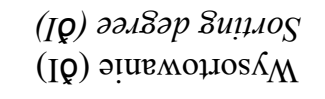 & $\begin{array}{l}8 \\
0 \\
\text { in }\end{array}$ & $\stackrel{n}{0}$ & $\stackrel{n}{\hat{\sigma}}$ & i & $\frac{\text { in }}{i}$ & $\stackrel{\stackrel{P}{t}}{\rightarrow}$ & ㅇ. & $\stackrel{n}{\infty}$ & $\frac{n}{0}$ \\
\hline 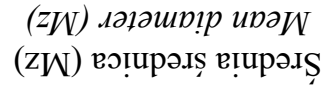 & $\begin{array}{l}\stackrel{\Omega}{\circ} \\
\forall\end{array}$ & $\stackrel{n}{m}$ & $\cong$ & $\underset{f}{\stackrel{P}{f}}$ & $\begin{array}{l}\curvearrowright \\
\infty \\
\forall\end{array}$ & $\begin{array}{l}8 \\
\stackrel{8}{0}\end{array}$ & $\begin{array}{l}\text { กิ } \\
\text { in }\end{array}$ & $\begin{array}{l}8 \\
n \\
n\end{array}$ & $\frac{n}{0}$ \\
\hline $\begin{array}{l}\text { (uய) } \\
\text { z00`0> }\end{array}$ & in & 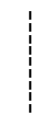 & 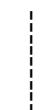 & กิ & $\begin{array}{l}20 \\
\text { n. }\end{array}$ & 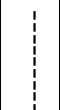 & $\hat{\sigma}_{0}$ & $\frac{\infty}{\nabla^{2}}$ & \\
\hline $\begin{array}{c}\text { (uш) } \\
200^{\circ} 0^{-}-8 \angle 00^{\circ} 0\end{array}$ & $\begin{array}{l}0 \\
\dot{ \pm}\end{array}$ & 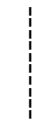 & 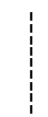 & $\tilde{\Xi}^{\prime}$ & 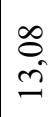 & 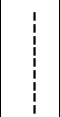 & $\hat{n}$ & $\stackrel{\mathscr{g}}{\stackrel{\Xi}{\Xi}}$ & 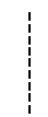 \\
\hline $\begin{array}{c}\text { (uய) } \\
8 \angle 00^{6} 0-90^{\circ} 0\end{array}$ & $\stackrel{\nabla_{0}}{=}$ & 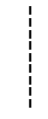 & 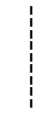 & 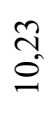 & $\frac{n}{a}$ & 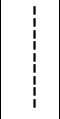 & $\stackrel{\infty}{=}$ & $\stackrel{\substack{n \\
0}}{0}$ & 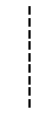 \\
\hline $\begin{array}{c}\text { (um) } \\
910^{6} 0-\varepsilon 90^{\circ} 0\end{array}$ & $\hat{\sigma}$ & b & $\hat{\sigma}$ & है & ñ & $\frac{n}{\infty}$ & $\begin{array}{l}n \\
\tilde{n} \\
n\end{array}$ & $\frac{\hat{y}}{\bar{y}}$ & $\hat{\sigma}$ \\
\hline $\begin{array}{c}\text { (uum) } \\
\varepsilon 90^{\circ} 0-\varsigma Z I^{\prime} 0\end{array}$ & గூ & $\tilde{n}$ & $\begin{array}{l}0 \\
\text { i }\end{array}$ & $\stackrel{\infty}{=}$ & $\begin{array}{l}\hat{\sigma} \\
\hat{=}\end{array}$ & $\stackrel{n}{2}$ & $\begin{array}{l}\text { ర్ } \\
\text { ह่ }\end{array}$ & $\frac{n}{2}$ & త్ \\
\hline $\begin{array}{c}\text { (uи) } \\
\varsigma I^{6} 0-\varsigma Z^{6} 0\end{array}$ & ñ & $\underline{-}$ & $\hat{a}$ & $r^{2}$ & $n$ & $\overrightarrow{\vec{\lambda}}$ & $\begin{array}{l}\bar{\sigma} \\
r\end{array}$ & $\bar{\sigma}^{\circ}$ & $\frac{0}{f}$ \\
\hline $\begin{array}{c}\text { (uum) } \\
\varsigma \tau^{6} 0-\varsigma^{6} 0\end{array}$ & $\vec{\infty}$ & $r$ & $\begin{array}{l}\infty \\
\underset{+}{+}\end{array}$ & $\stackrel{2}{0}$ & $\frac{\nabla}{i n}$ & $\frac{n}{\infty}$ & 6 & $m$ & $\stackrel{m}{\infty}$ \\
\hline $\begin{array}{l}\text { (uum) } \\
\varsigma^{6} 0^{-} 0^{6} \tau\end{array}$ & $\hat{n}^{\circ}$ & 0 & 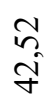 & $\hat{a}$ & $\begin{array}{l}\text { రం } \\
\text { å }\end{array}$ & $\begin{array}{l}0 \\
\stackrel{0}{n} \\
=\end{array}$ & 0 & 0 & $\hat{\sigma}$ \\
\hline 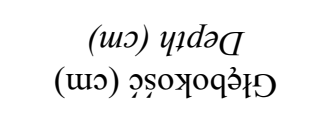 & $\frac{i}{\sim}$ & $\begin{array}{l}n \\
i \\
n \\
n\end{array}$ & $\begin{array}{l}8 \\
1 \\
n \\
\infty\end{array}$ & 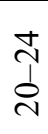 & 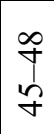 & $\begin{array}{l}n \\
1 \\
1 \\
6\end{array}$ & $\begin{array}{l}\infty \\
\infty \\
\infty\end{array}$ & $\begin{array}{l}\simeq \\
\beth \\
ٍ\end{array}$ & $\begin{array}{l}\stackrel{0}{n} \\
\text { n } \\
\text { n }\end{array}$ \\
\hline $\begin{array}{l}\text { ıәquпи әрдив } \\
\text { !rqo.ıd } \mathrm{IN}_{\mathrm{N}}\end{array}$ & - & $N$ & $n$ & - & $\sim$ & $m$ & $\nabla$ & $n$ & 0 \\
\hline 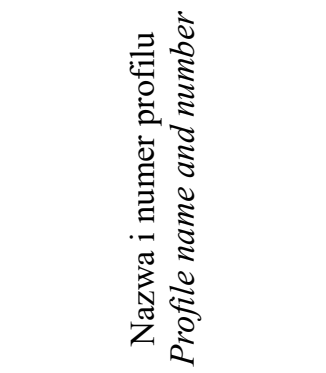 & & 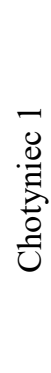 & & & & ? & & & \\
\hline
\end{tabular}


Litologia osadów w profilu Chotyniec 3

Lithology of sediments in the Chotyniec 3 profile

\begin{tabular}{|l|c|l|}
\hline $\begin{array}{l}\text { L.p. } \\
\text { Order number }\end{array}$ & $\begin{array}{c}\text { Głębokość }(\mathrm{m}) \\
\text { Depth }(\mathrm{m})\end{array}$ & $\begin{array}{l}\text { Litologia i struktura osadów } \\
\text { Lithology and structure of deposits }\end{array}$ \\
\hline 1. & $0,00-0,37$ & $\begin{array}{l}\text { pył o strukturze masywnej z licznymi korzeniami (poziom orny gleby), } \\
\text { koloru szarego }\end{array}$ \\
\hline 2. & $0,37-0,63$ & pył o strukturze masywnej popielaty z pieprzami żelazistymi \\
\hline 3. & $0,63-0,65$ & piasek drobnoziarnisty \\
\hline 4. & $0,65-1,02$ & pył popielatoszary z pieprzami manganowo-żelazistymi \\
\hline 5. & $1,02-1,20$ & pył o strukturze masywnej, koloru jasnobrązowego \\
\hline 6. & $1,20-1,37$ & piasek średnio- i gruboziarnisty z pojedynczymi żwirami, koloru rdzawego \\
\hline
\end{tabular}

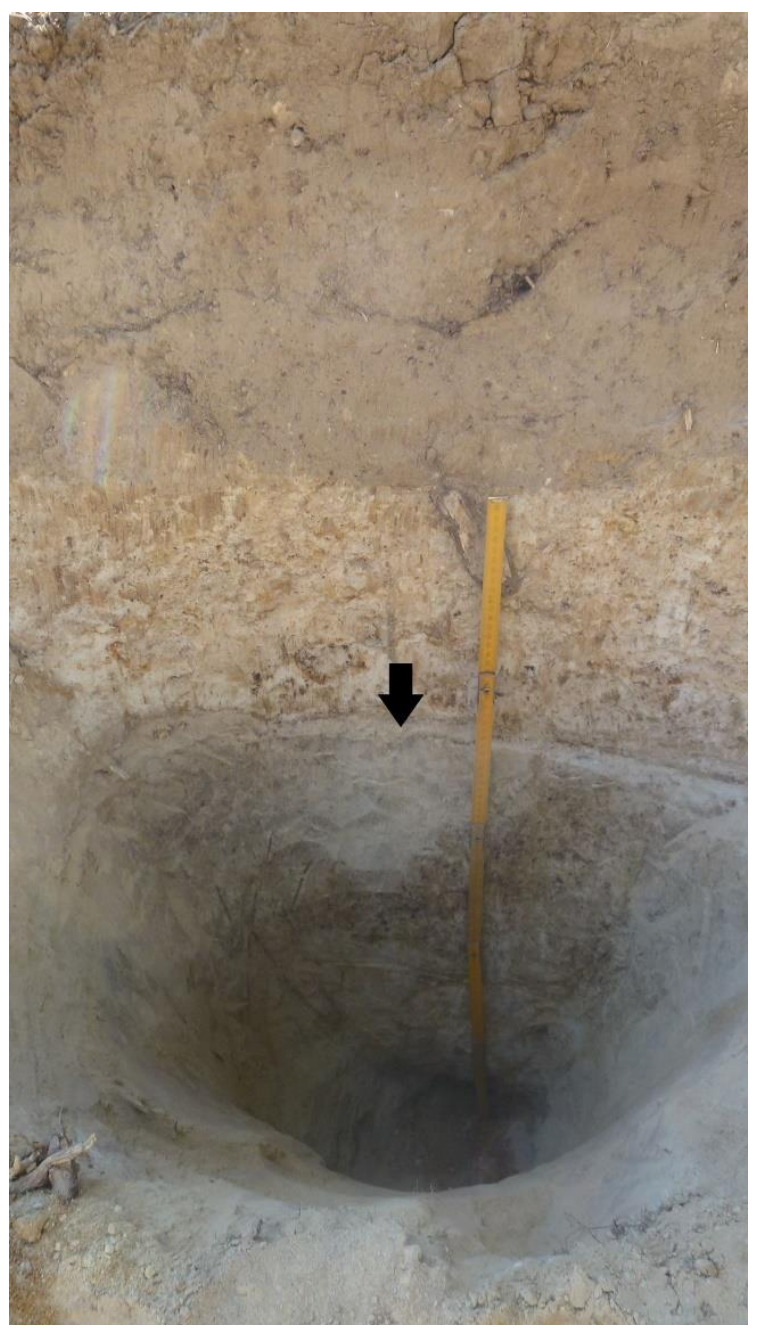

fot. P. Gębica, 2015

Fot. 6. Profil Chotyniec 3. Pyły masywne miąższości $1,2 \mathrm{~m}$ z laminą piasków na głębokości 63-65 cm, której położenie pokazuje strzałka

Chotyniec profile 3 . Silts with massive structure, $1,2 \mathrm{~m}$ thick with laminae of sands at the depth of $63-65 \mathrm{~cm}$, which location was showed by arrow 


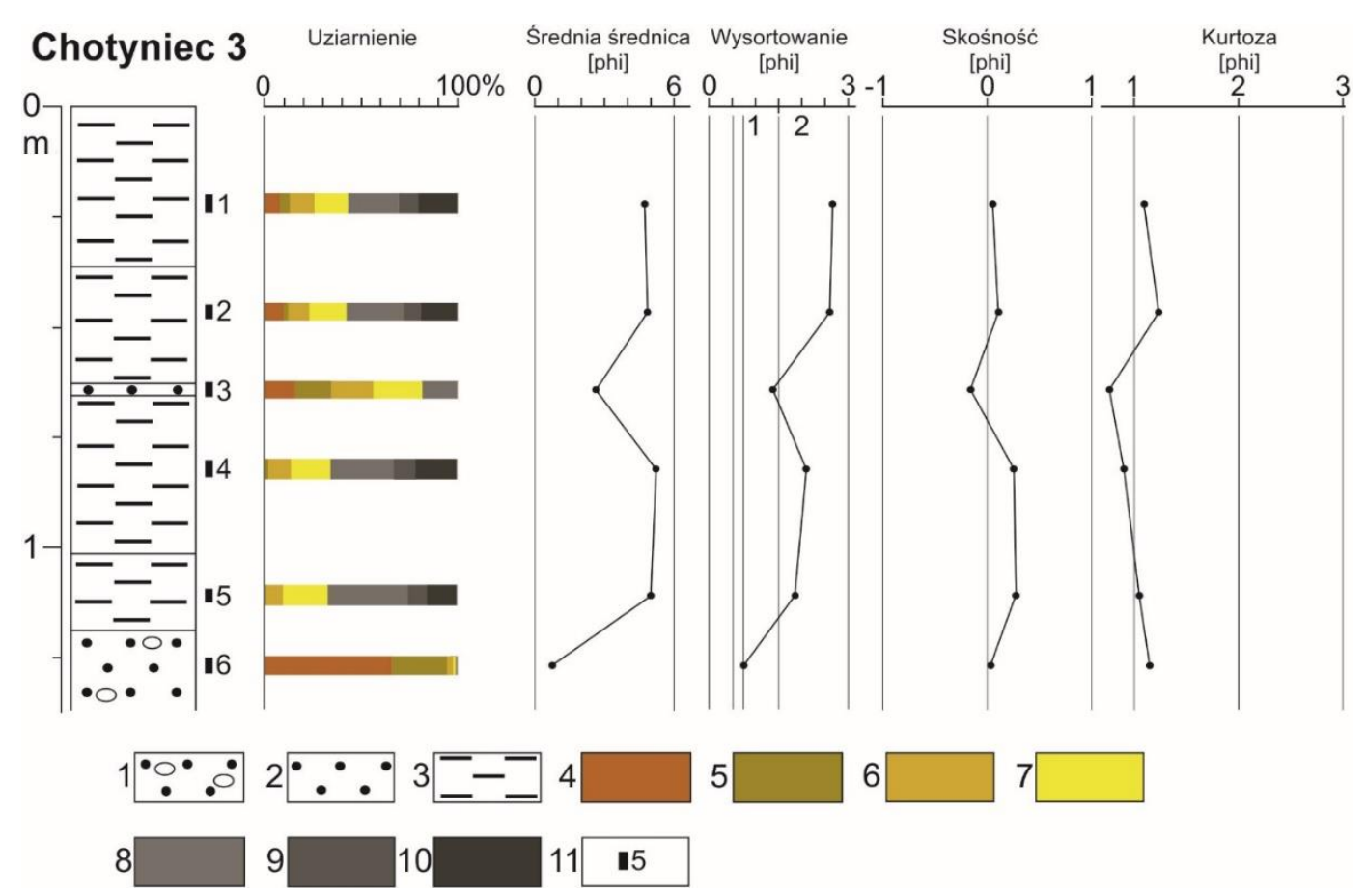

Rys. 9. Profil litologiczny (uziarnienie i wskaźniki według Folka, Warda 1957) pokrywy pyłów i osadów fluwioglacjalnych w profilu Chotyniec 3

1 - piasek ze żwirem, 2 - piasek, 3 - pył, 4 - piasek gruboziarnisty, 5 - piasek średnioziarnisty, 6 - piasek drobnoziarnisty, 7 - piasek bardzo drobnoziarnisty, 8 - pył gruboziarnisty, 9 - pył średnioziarnisty, 10 - pył drobnoziarnisty, 11 - lokalizacja i numer próbki na diagramie litologicznym

Lithological profile (grain size and indices after Folk, Ward 1957) silt cover and fluvioglacial deposits in the Chotyniec profile 3

1 - sand with gravel, 2 - sand, 3 - silt, 4 - coarse sand, 5 - medium sand, 6 - fine sand, 7 - very fine sand, 8 - coarse silt, 9 - medium silt, 10 - fine silt, 11 - location and sample number on the lithological diagram

\section{Dyskusja}

\section{Warunki akumulacji osadów czwartorzędowych}

Wyniki analizy uziarnienia oraz rzeźby terenu na stanowisku w Kalnikowie-Zagrebli 1 pozwoliły stwierdzić, że mamy do czynienia $\mathrm{z}$ wydmą wałową, o dwudzielnej budowie. Analiza uziarnienia wykazała, że średnia średnica ziarn (Mz) 2,9 phi (znacznie większa w porównaniu $\mathrm{z}$ opisywanymi w literaturze osadami wydmowymi) oraz dobre wysortowanie $\left(\delta_{\mathrm{I}}=0,5-\right.$ $0,6)$ upodabniają je do piasków wydmowych (Mycielska-Dowgiałło 1978, 2007). Dominującym osadem budującym górną część profilu $(0,0-1,2 \mathrm{~m})$ jest piasek drobnoziarnisty $(0,25-$ $0,125 \mathrm{~mm})$, którego udział wynosi $50-59,9 \%$. Zastanawia jednak bardzo duży udział piasku drobnoziarnistego w budowie wydmy oraz wysoka i jednakowa w całym profilu wartość $\mathrm{Mz}$ równa 2,9 phi (rys. 5, tab. 3). Upoważnia to do postawienia hipotezy, że osad ten był akumulo- wany w bardzo jednorodnych warunkach wiatrowych. Ponadto tak drobnoziarnisty osad budujący wydmy nie jest powszechnie spotykany w wydmach okresu schyłku plejstocenu. Racinowski i in. (2001) stwierdzają, że Mz osadów wydmowych zmienia się $\mathrm{w}$ zakresie od 2 do 4 phi. Eoliczne piaski pokrywowe w dolinie Wisły i osady wydmowe w zachodniej części Kotliny Sandomierskiej mają znacznie grubsze ziarno (Mz=1,5-2,2 phi) (Izmaiłow 2001; Gębica 2004), w porównaniu z osadami budującymi wydmę w Kalnikowie-Zagrebli. Wydmę w miejscowości Dąbrówki w dolinie Wisłoka, tworzy w stropie masywny piasek średnio- i drobnoziarnisty, z frakcją podstawową $0,355-0,25 \mathrm{~mm}$ (29\%), natomiast w spągu (poniżej $2 \mathrm{~m}$ ) przeważają osady $\mathrm{z}$ dużym udziałem frakcji piasku drobnoziarnistego $(0,25-0,125 \mathrm{~mm}), \quad(40,2-$ 45,6\%), których średnia średnica ziarn (Mz) mieści się w zakresie 1,74-1,98 phi (Gębica i in. 2016). Zieliński i Semeniuk (2008) podają, że wydmę wałową w Arłamowskiej Woli w dorzeczu Wiszni na Ukrainie, buduje piasek drobnoziarnisty i piasek pylasty, w którym udział pyłu 
dochodzi do 30\%. Wymienieni autorzy nie podają jednak wyników analiz uziarnienia. Natomiast analizowana przez Gębicę i in. (w druku) wydma w Zarzeczu na Ukrainie charakteryzuje się, podobnie jak w Kalnikowie-Zagrebli, wąskim zakresem średniej średnicy ziarn $(\mathrm{Mz}=2-3 \mathrm{phi})$, co wskazuje, że w składzie jej uziarnienia dominują ziarna frakcji piasku drobno- i bardzo drobnoziarnistego (80-85\%). Wydmy sandru kurpiowskiego budują osady, których $\mathrm{Mz}$ zmienia się zaledwie w zakresie 0,5 phi, tj. od 2,4 do 2,9 phi (Kowalska 2004; Kowalewska 2004). Podobnie Seppälä (2004) opisując wydmy z północnej Finlandii, podaje wartości w przedziale 0,1-0,3 mm (1,67-3,32 phi). Dodatnie wartości wskaźnika skośności mogą świadczyć o występowaniu warunków, w których następowało zmniejszenie prędkości wiatru powodujące unieruchomienie ziaren przemieszczanych w wyniku saltacji (Racinowski i in. 2001), jak również akumulację osadów drobnoziarnistych przemieszczanych w zawiesinie.

Poniżej pierwszego poziomu bruku, na stanowisku Kalników-Zagrebla 1, na głębokości 1,2 m (rys. 5, tab. 3) następuje zmiana skośności osadów na ujemną, co wskazuje na wzbogacenie materiału we frakcje grubsze, będące efektem eliminowania frakcji drobniejszych w czasie transportu. Według interpretacji litodynamicznej przedstawionej przez Racinowskiego i in. (2001) ujemne wartości wskaźnika skośności mogą wskazywać na przewagę prędkości ośrodka transportującego większych od przeciętnych, czego skutkiem jest akumulacja materiału gruboziarnistego. Zieliński (2016) podaje, że ujemne wartości skośności osadów wydmowych są związane $\mathrm{z}$ powierzchniami erozyjnymi/deflacyjnymi. Analiza uziarnienia wykazała, że w badanych osadach dominuje frakcja bardzo drobnego piasku $(0,125-0,063 \mathrm{~mm})$, której udział jest znacznie większy, niż w nadległych osadach wydmowych. Zarówno średnia średnica ziarn (Mz), jak i wysortowanie osadów $(\sigma \mathrm{I})$ wykazują dużą zmienność w profilu (rys. 5, tab. 3), co świadczy o zróżnicowanej dynamice ośrodka transportującego osad (Mycielska-Dowgiałło 2007). Duża różnorodność typów ziarn według analizy Cailleux (1942) z późniejszymi modyfikacjami wskazuje, że piaski ze żwirami poniżej $1,2 \mathrm{~m}$ pojawiają się na wtórnym złożu, jako efekt erozji osadów różnej genezy np. eolicznych i wodnych (Woronko 2001, 2012). Bardzo duży stopień zniszczenia powierzchni ziarn $\mathrm{w}$ wyniku działania wietrzenia chemicznego, może dowodzić, że osady te znajdowały się w zasięgu dzia- łania np. procesów glebowych. W tych warunkach nastąpiło zatarcie wszelkich mikrostruktur powstałych w czasie transportu ziarn poprzez działanie zarówno trawienia, jak i wytrącania. Opisane wyżej cechy teksturalne oraz udział klastów skał skandynawskich, pozwala zaliczyć piaski z brukami żwirowymi do utworów fluwioglacjalnych, związanych $\mathrm{z}$ działalnością wód wypływających z lądolodu zlodowacenia sanu (Wójcik 2008). Świadectwem denudacji (rozmywania) osadów wodnolodowcowych w młodszych okresach czwartorzędu są spoczywające bezpośrednio na iłach krakowieckich, na zboczu doliny Wiszni - żwiry, zawierające klasty skał skandynawskich, które interpretujemy jako żwiry rezydualne.

Piaski terasy nadzalewowej Wiszni na stanowisku w Kalnikowie-Zagrebli 2-II, pod względem parametrów uziarnienia przypominają osady wydmowe na stanowisku w KalnikowieZagrebli 1. Frakcja podstawowa w badanych osadach aluwialnych, podobnie jak w piaskach wydmowych, to $0,25-0,125 \mathrm{~mm}(50-65,4 \%)$. Wysortowanie osadu jest umiarkowane i dobre, a wartość skośności (Sk) w całym profilu nie ulega wyraźnym zmianom i zawiera się $\mathrm{w}$ przedziale $0,5-1,0$ phi. Aluwia terasowe charakteryzują się stopniowym wzrostem średniej średnicy w jednostkach phi (Mz) od 2,4 do 2,8 phi w górę profilu, w stosunku do osadów wydmowych (rys. 4, tab. 3), co oznacza drobnienie osadu ku stropowi młodszego ogniwa aluwiów terasy. Najbardziej wyróżniajacą się względem uziarnienia jest próbka nr 8, zawierająca ponad $95 \%$ piasku drobno- i bardzo drobnoziarnistego (rys. 4, tab. 3), reprezentująca prawdopodobnie stropową część starszego ogniwa aluwiów terasy vistuliańskiej. Taki rozkład parametrów uziarnienia i pozioma laminacja osadów wynika z powtarzających się cyklicznie zalewów warstwowych i akumulacji w przykorytowej równi zalewowej (Gębica 2004; Zieliński 2016).

Analizowany pod względem uziarnienia profil Chotyniec 3, jest bardzo podobny do utworów pyłowych na stanowisku Żmijowiska na Płaskowyżu Lubaczowsko-Jaworowskim w dorzeczu rzeki Szkło (Wojtanowicz 1997), które wymieniony autor wiązał $\mathrm{z}$ wietrzeniem peryglacjalnym - produkt wietrzenia mrozowego w klimacie peryglacjalnym. Wiek pokrywy pylastej określono w profilu Żmijowiska metodą TL na $15000 \pm 3000$ BP (Lub-3206), co odpowiada schyłkowi plenivistulianu (Wojtanowicz 1997). Jednakże położenie pokrywy osadów pylastych w pozycji wierzchowinowej, na pia- 
skach ze żwirami oraz znacznie mniejszy udział frakcji piaszczystej w spągu profilu $(32,46-$ $34,23 \%$ ) niż w jego stropowej części (>40\%) (rys. 9, tab. 8), wyklucza wietrzeniową genezę osadów w Chotyńcu. Masywna struktura utworów pyłowych, znaczny udział frakcji „lessowej” (typowej dla lessu) $0,063-0,016 \mathrm{~mm}(26,8-$ $41,7 \%$ ) oraz średnia średnica $M z=5,2-4,7$ phi pozwalają przypuszczać, że osady pylastopiaszczyste w Chotyńcu mają również genezę eoliczną, zbliżoną składem uziarnienia do lessu. Różnią się jednak większym udziałem piasku i obecnością lamin (przewarstwień) piaszczystych (less piaszczysty) w pobliżu wychodni piasków wodnolodowcowych. Potwierdzeniem takiej interpretacji jest występowanie pokryw lessowych na garbach płaskowyżu w rejonie Buczyny ponad doliną Szkła i na południe od Chotyńca, opisanych przez Wójcika (Wójcik 1999, 2008). Natomiast na Szczegółowej mapie geologicznej Polski 1:50 000, arkusz Radymno, w miejscu analizowanych pokryw osadów pylastych w Chotyńcu wyróżniono glinę lodowcową (Wójcik 2008). Obecność lamin grubszego materiału w osadach lessowych może wynikać z bliskości źródła materiału piaszczystego lub ze zmiennej prędkości wiatru.

\section{Wpływ budowy geologicznej i rzeźby terenu na osadnictwo na Plaskowyżu Tarnogrodzkim}

Rozpoznanie geologiczne i szczegółowa analiza strukturalna i teksturalna osadów na stanowiskach archeologicznych w Kalnikowie i Chotyńcu pozwoliły przypuszczać, jakie cechy krajobrazu, tj. rzeźba terenu, a w drugiej kolejności, możliwe że i budowa geologiczna utworów powierzchniowych, miały największe znaczenie przy wyborze miejsc pod osadnictwo w czasach prahistorycznych.

Stanowisko Kalnikow-Zagrebla 1 zlokalizowane zostało na skłonie doliny Wiszni, na wydmie, wznoszącej się około $2 \mathrm{~m}$ ponad otaczający teren. Osady piaszczyste zapewniały z jednej strony łatwość przeprowadzania wszelkich prac ziemnych, $\mathrm{z}$ drugiej zaś nie były narażone na podtopienia i dużą wilgotność. Takiej lokalizacji mogło sprzyjać również położenie na zawietrznej tj. południowo-wschodniej i południowej stronie wzniesienia i południowa ekspozycja. Zapewniało to schronienie w przypadku wystąpienia silnego wiatru, zapobiegało przesuszaniu gruntu, ułatwiało wsiąkanie wód opadowych i roztopowych oraz przyspieszało tajanie pokrywy śnieżnej. Ponadto położenie na skłonie doliny rzecznej, mogło być dobrym punktem obserwacyjnym. Taka lokalizacja osad w czasach prehistorycznych i historycznych jest często spotykana w różnych regionach świata (Moskwa 1976; Rapp, Hill 1998; Pelisiak, Gębica 2007; Kittel 2013; Czopek 2014).

Stanowisko Kalnikow-Zagrebla 2 (profile I, II, III) zostało zlokalizowane na terasie nadzalewowej (vistuliańskiej) Wiszni, wznoszącej się na wysokości 6-8 m nad poziomem współczesnej rzeki. Takie położenie stanowiska archeologicznego wskazuje, że w czasach historycznych ludzie najprawdopodobniej nie byli narażeni na powodzie, a z drugiej strony mieli łatwy i ciągły dostęp do wody pitnej. O atrakcyjności tego miejsca może również świadczyć fakt, iż w czasie I wojny światowej założono tam okopy służące zarówno do obrony, zabezpieczania przeprawy przez rzekę, jak i zapewne dogodnej obserwacji terenu.

Stanowisko archeologiczne Chotyniec z dobrze zachowanym wałem grodziska z VII-VI w. p.n.e., zostało zlokalizowane na prawie płaskiej wierzchowinie o wysokości 204-206 m n.p.m. pokrytej utworami pylasto-piaszczystymi. Wytworzone na tych osadach gleby typu bielicowego (Borowiec 1974) można zaliczyć do gleb o niskiej wartości użytkowej. Najprawdopodobniej o atrakcyjności tego rejonu zadecydował równinny, wysoko położony teren, umożliwiający prowadzenie gospodarki bez większych przeszkód terenowych. Wysoczyzny mogły być również wykorzystane, jako tereny pastwiskowe. Ponadto takie położenie dawało możliwość łatwej obserwacji terenów otaczających.

\section{Podsumowanie i wnioski}

Badania cech strukturalnych i teksturalnych osadów budujących południową część Płaskowyżu Tarnogrodzkiego wykazały duże zróżnicowanie litologiczne i genetyczne utworów czwartorzędowych występujących w rejonie stanowisk archeologicznych w Kalnikowie i Chotyńcu.

Najstarsze analizowane osady to piaski i żwiry fluwioglacjalne $z$ domieszką materiału skandynawskiego, charakteryzujące się bardzo zmiennymi wskaźnikami uziarnienia. Są to utwory akumulowane przez wody roztopowe lądolodu zlodowacenia sanu około 500 tys. lat temu (Wójcik 2008). Analiza obróbki ziaren kwarcu wykazała, że osady te charakteryzują się 
dużą różnorodnością typów ziarn, co może wskazywać, że znajdują się na wtórnym złożu jako efekt erozji starszych osadów wodnych i eolicznych. Najprawdopodobniej redepozycja osadów miała miejsce po okresie zlodowacenia sanu i była związana $\mathrm{z}$ erozyjnym pogłębianiem dolin. W stropie osadów wodnolodowcowych pokrywa miąższości około $1,2 \mathrm{~m}$ reprezentuje piaski eoliczne budujące wydmę w KalnikowieZagreblach. Datowanie piasków metodą OSL wykazało młododryasowy wiek wydmy, a więc najmłodszej trzeciej fazy (późnoglacjalnej) tworzenia wydm w Kotlinie Sandomierskiej (Wojtanowicz 2003).

Innego pochodzenia i wieku są piaski terasy nadzalewowej Wiszni o wysokości 6-8 m n.p.rz. Charakteryzuje je pozioma laminacja osadów, bardzo drobnoziarniste uziarnienie i stopniowy wzrost wartości średniej średnicy (w skali phi) w górę profilu, co wskazuje na drobnienie osadów ku stropowi. Wymienione parametry osadów są wynikiem akumulacji w strefie przykorytowej równi zalewowej (Gębica 2004; Zieliński 2016). Pod względem struktury i wskaźników uziarnienia osady te przypominają inne analizowane profile aluwiów terasy o wysokości 8-12 m n.p.rz. datowane na vistulian (Gębica 2004).

Niewielkiej miąższości utwory pokrywowe w Chotyńcu leżące na piaskach i żwirach fluwioglacjalnych, ze względu na masywną strukturę oraz znaczny udział frakcji pylastej (powyżej 50\%) i domieszkę piasku (27-44\%) zostały również zaklasyfikowane, jako osady pochodzenia eolicznego (less piaszczysty) (Wojtanowicz 1997; Buraczyński 1994). Zatem nie są to gliny lodowcowe, jak oznaczono na Szczegółowej mapie geologicznej Polski 1:50 000, arkusz Radymno (Wójcik 2008).

Wyniki badań pokazały, że w czasach prahistorycznych i historycznych miejsca wyboru lokalizacji osad i prowadzonej działalności gospodarczej nie były przypadkowe. Każde z analizowanych stanowisk miało dogodne warunki topograficzne, wilgotnościowe, glebowe czy też obronne, które były postrzegane przez ówczesnych ludzi, jako walory środowiska.

\section{Podziękowania}

Datowania metodą OSL, badania terenowe i część analiz laboratoryjnych sfinansowano z grantu NCN nr 2013/09/B/HS3/04277 pt. „Przemiany kulturowo-osadnicze $\mathrm{w}$ dorzeczu rzeki Wiszni w epoce brązu i we wczesnej epoce żelaza w kontekście zmian prahistorycznej i wczesnośredniowiecznej ekumeny" kierowanego przez. Prof. Sylwestra Czopka z Instytutu Archeologii Uniwersytetu Rzeszowskiego.

Dziękujemy mgr Mateuszowi Sobuckiemu, doktorantowi $\mathrm{z}$ Laboratorium Zakładu Geomorfologii UJ w Krakowie, za wykonanie analiz uziarnienia kilku próbek w profilu Chotyniec. Anonimowym recenzentom serdecznie dziękujemy za wszystkie uwagi merytoryczne i uzupełnienia poczynione w tekście artykułu.

\section{Literatura}

Adamiec G., Aitken M.J. 1998. Dose-rate conversion factors: update. Ancient TL 16: 37-50.

Borowiec J. 1974. Charakterystyka utworów pyłowych południowo-wschodniego krańca Płaskowyżu Tarnogrodzkiego. Annales UMCS, sec. B 29(7): 143-158.

Buraczyński J. 1994. Zmienność procesów eolicznych na Roztoczu i w Kotlinie Sandomierskiej podczas piętra Wisły. Annales UMCS, sec. B 49(4): 51-79.

Butrym J. 1968. Utwory pyłowe wschodniej części Niziny Sandomierskiej. Annales UMCS, sec. B 23(4): 87-127.

Cailleux A. 1942. Les actiones eoliennes periglaciaires en Europe. Mm. Soc. Geol. De France 41: $1-176$.

Carlson A.E. 2013. The Younger Dryas Climate Event. W: S.A. Elias (red.) The Encyclopedia of Quaternary Science, vol. 3. Amsterdam, Elsevier: 126-134.

Czopek S. 2001. Pysznica, pow. Stalowa Wola, stanowisko 1 - cmentarzysko ciałopalne z przełomu epok brązu i żelaza. Wyd. Uniwersytetu Rzeszowskiego, Rzeszów: 1-320.

Czopek S. 2007. Grodzisko Dolne, stanowisko 22 wielokulturowe stanowisko nad dolnym Wisłokiem, cz. 1, od epoki kamienia do wczesnej epoki żelaza. Fundacja Rzeszowskiego Ośrodka Archeologicznego, Instytut Archeologii Uniwersytetu Rzeszowskiego, Muzeum Okręgowe w Rzeszowie, Rzeszów: 1-241.

Czopek S. 2014. Stanowisko 158 w Jarosławiu, woj. podkarpackie. Część II. Osadnictwo od starszej epoki brązu do okresu rzymskiego. Via Archaeologica Ressoviensia, t. IV, Fundacja Rzeszowskiego Ośrodka Archeologicznego, Rzeszów: 1-207.

Czopek S., Trybała-Zawiślak K., Tokarczyk T., Tokarczyk E., Burghardt M., Adamik-Proksa J., Rajpold W. w druku. Pierwsze sprawozdanie z weryfikacyjnych badań na grodzisku z wczesnej epoki żelaza w Chotyńcu. Sprawozdania i Materiały Rzeszowskiego Ośrodka Archeologicznego, tom 38.

Folk L.R., Ward W.C. 1957. Brazos river bar: a study in the significance of grain size parameters. Journal of Sedimentary Petrology 27,1: 3-26. 
Galbraith R.E., Roberts R.G., Laslett G.M., Yoshida H., Olley J.M. 1999. Optical dating of single and multiple grains of quartz from Jinmium rock shelter, northern Australia, part I: Experimental design and statistical models. Archaeometry 4(2): 339-364.

Gębica P. 2004. Przebieg akumulacji rzecznej w górnym vistulianie w Kotlinie Sandomierskiej. Prace Geograficzne IGiPZ PAN 193: 1-229.

Gębica P., Bluszcz A., Woronko B. 2016. Geneza i wiek wydmy w Dąbrówkach (Kotlina Sandomierska, dolina Wisłoka) w świetle analiz litologicznych osadów i datowań OSL. W: J. Święchowicz, A. Michno (red.) Wybrane zagadnienia geomorfologii eolicznej. Instytut Geografii i Gospodarki Przestrzennej, Kraków: 305-330.

Gębica P., Jacyszyn A., Wacnik A. w druku. Warunki naturalne doliny Sanu i Wiszni jako czynnik determinujący osadnictwo prahistoryczne i wczesnośredniowieczne. W: S. Czopek i in. (red.) Przemiany kulturowo-osadnicze $w$ dorzeczu rzeki Wiszni w epoce brazu $i$ we wczesnej epoce żelaza $w$ kontekście zmian prahistorycznej $i$ wczesnośredniowiecznej ekumeny.

Izmaiłow B. 2001. Typy wydm śródlądowych w świetle badań struktury i tekstury ich osadów (na przykładzie dorzecza górnej Wisły). Rozprawy Habilitacyjne UJ, 358, Kraków: 1-282.

Kittel P. 2013. Geomorfologiczne uwarunkowania lokalizacji osadnictwa na przykładzie doliny Rawki w Rawie Mazowieckiej. Acta Geographica Lodziensia 101: 49-79.

Kowalewska M. 2004. Rozwój procesów eolicznych w południowej części sandru kurpiowskiego. Maszynopis pracy magisterskiej. WGSR UW, Warszawa.

Kowalska M. 2004. Porównanie cech teksturalnych różnowiekowych osadów eolicznych w południowo-zachodniej części sandru kurpiowskiego. Maszynopis pracy magisterskiej. WGSR UW, Warszawa.

Krumbein W.C. 1941. Measurement and geological significance of shape and roundness of sedimentary particles. Journal of Sedimentary Petrology 11(2): 64-72.

Łomnicki A.M. 1900. Atlas geologiczny Galicyi, tekst do zeszytu 12, arkusz: Mościska, Lubaczów, Płazów, Jarosław, Leżajsk, 1:75000. Wyd. Komisji Fizjogr. PAU, Kraków.

Moskwa K. 1976. Kultura łużycka w południowo-wschodniej Polsce. Wyd. Muzeum Okręgowego w Rzeszowie, Rzeszów: 1-386.

Mycielska-Dowgiałło E. 1978. Rozwój rzeźby fluwialnej północnej części Kotliny Sandomierskiej w świetle badań sedymentologicznych. Rozprawy UW, Warszawa.
Mycielska-Dowgiałło E., 2001. Wnioski końcowe, W: E. Mycielska-Dowgiałlo (red.) Eolizacja osadów jako wskaźnik stratygraficzny czwartorzędu, Warszawa: 125-129.

Mycielska-Dowgiałło E. 2007. Metody badań cech teksturalnych osadów klastycznych i wartość interpretacyjna wyników. W: E. Mycielska-Dowgiałło, J. Rutkowski (red.) Badania cech teksturalnych osadów czwartorzędowych $i$ wybrane metody oznaczania ich wieku. WSWPR, Warszawa: 95-180.

Mycielska-Dowgiałło E., Woronko B. 1998. Analiza obtoczenia i zmatowienia powierzchni ziarn kwarcowych frakcji piaszczystej i jej wartość interpretacyjna. Przeglad Geologiczny 46: 1275-1281.

Pelisiak A., Gębica P. 2007. Podstawy geomorfologii i gleboznawstwa dla archeologów. Mitel, Rzeszów: 1-200.

Racinowski R., Szczypek T., Wach J. 2001. Prezentacja i interpretacja wyników badań uziarnienia osadów czwartorzędowych. Wyd. Uniwersytetu Śląskiego, Katowice.

Rapp G.R., Hill C.L. 1998. Geoarchaeology: The Earth-science approach to archaeological interpretation. Yale University Press, New Haven and London: 1-274.

Seppälä M. 2004. Wind as a geomorphic agent in cold climates. Cambridge University Press.

Starkel L. 1972. Kotlina Sandomierska. W: M. Klimaszewski (red.) Geomorfologia Polski, t. 1. PWN, Warszawa: 138-166.

Trachsel M. 2004. Untersuchungen zur relativen und absolutenChronologie der Hallstattzeit, Universitätsforschungen zur prähistorischen Archäeologie, B. 104, Teil 1-2. Dr Rudolf Habelt GmbH, Bonn:1-620.

Urbaniak-Biernacka U. 1975. Propozycja terminologii dla przedziałów klasowych stopniowanej skali wielkości okruchów skalnych. Przegląd Geograficzny 47,1: 147-152.

Wentworth Ch.K. 1922. A scale of grade and class terms for clastic sediments. Journal of Geology 30: 377-392.

Wojtanowicz J. 1978. Rozwój nizinnej części doliny Sanu na tle paleogeomorfologii Kotliny Sandomierskiej. Rozprawa habilitacyjna, UMCS, Lublin: 1-114.

Wojtanowicz J. 1997. Profil Żmijowiska - problem powstania cienkich pokryw pylastych. Seminarium terenowe ,Glacjał i peryglacjał Kotliny Sandomierskiej i przedgórza Karpat w okolicy Przemyśla, Krasiczyn, 22-24 IX 1997, Lublin: 57-59.

Wojtanowicz J. 2003. Plenivistulian dunes in Poland - a new view on the development phases of inland dunes. Prace Geograficzne IGiPZ PAN 189: 41-60.

Woronko B. 2001. Znaczenie analizy obtoczenia i zmatowienia powierzchni ziarn kwarcowych 
frakcji piaszczystej w interpretacji genetycznej osadów czwartorzędowych. W: E. MycielskaDowgiałło (red.) Eolizacja osadów czwartorzędowych jako wskaźnik stratygraficzny czwartorzędu. Pracownia Sedymentologiczna WGiRS UW: 59-64.

Woronko B. 2012. Zapis procesów eolicznych w piaszczystych osadach plejstocenu na wybranych obszarach Polski środkowej i północno-wschodniej. Wydział Geografii i Studiów Regionalnych, Warszawa: 1-130.

Woronko B., Zieliński P., Sokołowski R.J. 2015. Climate evolution during the Pleniglacial and Late Glacial as recorded in quartz grain morphoscopy of fluvial to aeolian successions of the European Sand Belt. Geologos 21, 2: 89-103

Wójcik A. 1999. Objaśnienia do Szczegółowej mapy geologicznej Polski 1:50 000, arkusz Radymno (1008). Centr. Arch. Geol. PIG, Warszawa: $1-86$.

Wójcik A. 2002. Szczegółowa mapa geologiczna Polski 1:50 000, arkusz Krakowiec, PIG, Warszawa.

Wójcik A. 2008. Objaśnienia do Szczegółowej mapy geologicznej Polski 1:50 000, arkusz Krakowiec. PIG, Warszawa: 1-36.

Zieliński P. 2016. Regionalne i lokalne uwarunkowania późnovistuliańskiej depozycji eolicznej w środkowej części europejskiego pasa piaszczystego. Wyd. UMCS, Lublin: 1-234.

Zieliński P., Semeniuk I. 2008. Strukturalny zapis procesów akumulacyjno-deflacyjnych w wydmie wałowej we wschodniej części Kotliny Sandomierskiej (Ukraina). Annales UMCS, sec. B, LXIII,9: 169-176.

\section{Summary}

The article discusses the results of grain size and quartz grain roundness analyses, as well as OSL datings of the Quaternary deposits (aeolian, fluvial, fluvioglacial) differing in origin and age that occur in the southern part of the Tarnogród Plateau. The grain size and quartz grain roundness analyses allowed us to determine aeolian, fluvioglacial and fluvial deposits in the Kalników and Chotyniec archaeological sites. The dune sediments of a thickness of $1.2 \mathrm{~m}$ are characterized by the domination of fine grains with the mean diameter $\mathrm{Mz}=2.9$ phi. Such fine sediments are unusual in the Late Glacial dunes in the Sandomierz Basin. The deposition of the dune was dated by the OSL to the Younger Dryas. The dunes are underlain by fine sands with three thin gravel horizons. The great differentiation of grain types according to the Cailleux (1942) classification (modified), indicates that sand with gravel below a depth of $1.2 \mathrm{~m}$, represent the redeposited sediments due to the erosion of older sediments of various origin, for example aeolian and fluvial ones. The textural features and the occurrence of clasts of Scandinavian origin, suggest that these sediments represent fluvioglacial deposits connected with the activity of proglacial waters during the San Glaciation. Due to the subsequent denudation of fluvioglacial sediments, the gravel residuum rests on the slope of the Wisznia River valley over the Miocene Krakowiec Beds.

The terrace of the Wisznia River 6-8 m above the river channel is built of horizontally bedded sands, which also form the natural levees on the terrace surface. The large content of fine sand fraction and the values of grain size indices, indicate great similarity with dune sands. Observations of the terrace morphology and structure in the several transects along the Wisznia valley to the junction with the terrace $8-12 \mathrm{~m}$ high in the San River valley, make it possible to attribute the age of this terrace to the Vistulian Glaciation.

In the Chotyniec site, silty sediments covering the plateau around the hill-fort rampart from the Celtic Period were analysed. The occurrence of silt sediments overlying the sands with gravels and increasing upward content of sand fraction exclude their weathering origin. Grain size indices and a great content of silt fraction typical for loess $(0.06-0.02 \mathrm{~mm})$ reaching $41 \%$, resemble silty-sandy sediments of aeolian origin deposited during the Plenivistulian period. 